\title{
Resilience and regime change in a southern Rocky Mountain ecosystem during the past 17000 years
}

\author{
T. A. Minckley, ${ }^{1,4}$ R. K. Shriver,,${ }^{1,5}$ And B. Shuman ${ }^{2,3}$ \\ ${ }^{1}$ University of Wyoming, Department of Botany, Laramie, Wyoming 82071 USA \\ ${ }^{2}$ University of Wyoming, Department of Geology and Geophysics, Laramie, Wyoming 82071 USA \\ ${ }^{3}$ University of Wyoming, Program in Ecology, Laramie, Wyoming 82071 USA
}

\begin{abstract}
Paleoecological records indicate that subalpine forests in western North America have been resilient in response to multiple influences, including severe droughts, insect outbreaks, and widely varying fire regimes, over many millennia. One hypothesis for explaining this ecosystem resilience centers on the disruption of forest dynamics by frequent disturbance and climatic variability, and the resulting development of non-steady-state regimes dominated by early-successional conifers with broad climatic tolerances, such as lodgepole pine (Pinus contorta var. latifolia Engelm. ex Wats.). To evaluate this hypothesis, we independently reconstructed the vegetation, fire, and effective-moisture histories of a small, forested watershed at $2890 \mathrm{~m}$ elevation in southeastern Wyoming, USA, using sedimentary pollen and charcoal counts in conjunction with sedimentary lake-level indicators. The data indicate that prominent vegetation shifts (from sagebrush steppe to spruce-fir parkland at ca. $10.7 \mathrm{ka}$ and spruce-fir parkland to pine-dominated forest at ca. $8.5 \mathrm{ka}$ [ka stands for thousands of years before the present, defined as AD 1950]) coincided with changes in effective moisture. However, after lodgepole pine forests established at ca. $8.5 \mathrm{ka}$, similar hydroclimatic changes did not produce detectable vegetation responses. Fire history data show that other aspects of the ecosystem were responsive to changes in effective moisture at centennial timescales with prolonged fire-free episodes coinciding with periods of low effective moisture ca. 7.2-5.6 and 3.7-1.6 ka. Throughout our record, the ratio of ecosystem perturbation time (i.e., fire frequency and changes in effective moisture) to recovery time (assuming 200-600year successional processes) falls within estimates of the ratio for non-steady state ecosystems. Frequent perturbations, therefore, may have prevented this ecosystem from reaching compositional equilibrium with the varied climatic conditions over the past $8.5 \mathrm{ka}$. Equilibrium states could have included more abundant spruce (Picea spp.) and fir (Abies spp.) than presently observed based on brief increases in pollen abundances of these taxa during prolonged dry, fire-free intervals. Our results show that, although current climate changes favor widespread disturbance in Rocky Mountain forests, the composition of these ecosystems could be highly resilient and recover through successional dynamics over the next few decades to centuries.
\end{abstract}

Key words: climate-vegetation relationships; ecosystem resilience; effective moisture; fire frequency; palynological analysis; Rocky Mountains, USA.

\section{INTRODUCTION}

Recent warming and drought in the western United States has caused substantial regional ecosystem change, including increased background rates of tree mortality (van Mantgem et al. 2009), drought-induced ecotone shifts (Breshears et al. 2005, Worrall et al. 2008), largescale insect outbreaks (Raffa et al. 2008, Wulder et al. 2010), and extended fire seasons with increased annual area burned (Westerling et al. 2003, 2006). Such changes have raised concerns that climate change could produce widespread ecosystem regime shifts (Fagre et al. 2009).

Manuscript received 22 February 2011; revised 9 June 2011; accepted 26 August 2011. Corresponding Editor: A. H. Lloyd.

${ }^{4}$ E-mail: minckley@uwyo.edu

${ }^{5}$ Present address: Duke University, University Program in Ecology, Durham, North Carolina 27708 USA.
Paleoecological records provide a unique opportunity to examine regime shifts and to evaluate their long-term outcomes. In the western United States, however, many paleoecological records from subalpine forests show little vegetation change over many millennia. For example, forested ecosystems in the northern Rocky Mountains were repeatedly disturbed by severe fires and insect outbreaks, but many sites maintained similar vegetation composition for $>8000$ years (Baker 1983, Macdonald 1989, Millspaugh et al. 2000, Brunelle and Whitlock 2003, Brunelle et al. 2005). The basis for the apparent stability has not been well explained, beyond edaphic controls in the case of the Yellowstone Plateau. Some of these western ecosystems may act as "self-organized" systems where species effects and interactions among system components determine ecosystem composition and structure more than abiotic factors (Suding and Hobbs 2009); 
interactions among vegetation and disturbance, particularly fire, can be one such determinant (Wright 1974, Romme and Knight 1981, Green 1982, Davis and Botkin 1985, Overpeck et al. 1990, Turner et al. 1993).

Ecosystem resilience has been defined as "the amount of change a system can undergo and...stay in the same regime," (Suding and Hobbs 2009). Such resilience can result from intrinsic dynamics that rapidly return an ecosystem to its prior state or trajectory following perturbation (e.g., succession following severe fire [Turner et al. 1993]). Climatic changes can often push ecosystems beyond their range of resilience, and as a result, paleoecological records commonly include evidence of past ecosystem regime shifts (exemplified by transitions from one phase of vegetation history to another recorded as boundaries between stratigraphically distinct fossil pollen assemblages). We use the term "regime" to denote a particular ecosystem state (i.e., vegetation composition and fire regime), and "phase" to represent distinct time periods when our study site remained within one regime. (Conceptually, a single "regime" could be repeated during different "phases.")

Many paleoecological records show multiple regimes shifts over a period of several millennia (e.g., Jacobson and Grimm 1986, Grimm and Jacobson 1992, Lytle 2005), but records from the Rocky Mountains contain few such shifts. Forest composition has remained similar at many sites for multiple millennia (Baker 1983, Macdonald 1989, Whitlock and Bartlein 1993, Fall 1997, Brunelle et al. 2005, Minckley et al. 2007). In contrast to the apparent stability of Rocky Mountain subalpine forests, northern boreal, deciduous, and mixed forests in eastern North America and Europe have undergone repeated regime shifts since the last ice age (Deevey 1939, Davis 1969, Huntley and Birks 1983, Gaudreau and Webb 1985, Huntley and Webb 1989, Anderson and Brubaker 1994), which have been well explained by both temperature and hydroclimatic changes (Dean et al. 1984, Shuman et al. 2004, Nelson and $\mathrm{Hu}$ 2008). In this context, the stability of Rocky Mountain forests is surprising given evidence of severe regional droughts and rapid hydroclimatic changes (Stone and Fritz 2006, Shuman et al. 2009, 2010), including episodes of aridity severe enough to prohibit persistent water flow in major regional rivers (Shinker et al. 2010) and to activate mid-continent and intermontane dune fields (Ahlbrandt and Andrews 1978, Mayer and Mahan 2004, Miao et al. 2007).

Modern climate-vegetation relationships provide a framework for anticipating high resilience and resulting stability of pine-dominated forests in the Rocky Mountains, as well as the potential for more frequent regime changes in other forest types (Minckley et al. 2008). In particular, many western tree taxa occupy broader climatic niches (sensu Jackson and Overpeck 2000) than taxa in other regions, and western pines (Pinus spp.) tolerate a wider range of moisture availability than any other tree taxon in North America
(Fig. 1) (Thompson et al. 1999, Williams et al. 2006, Minckley et al. 2008, Williams and Shuman 2008). The broad climatic niches may result from the strong influence of fire and other disturbances (Wright 1974). Severe disturbances prohibit the development of steady states in subalpine forests (Romme and Despain 1989), and as a consequence, favor generalist pioneer taxa, exemplified by lodgepole pine (Pinus contorta var. latifolia Engelm. ex Wats.).

Multiple studies have identified that lodgepole pine forests can experience little compositional turn-over because of limited successional replacements, particularly on dry sites (Whipple and Dix 1979, Peet 1981, Despain 1983). Fire especially limits the recruitment of other taxa (Romme and Knight 1982), as has also been noted in fire-prone forests in eastern North America where Holocene climatic changes have induced little compositional change (Wright 1974, Green 1982, Winkler 1985, Maenza-Gmelch 1997, Tweiten et al. 2009). One reason for such stability may be that similar time scales of forest succession, disturbance (fire), and climatic variability favor compositionally stable and structurally variable disequilibrium states (Webb 1986, Turner et al. 1993); frequent disturbance potentially obscures responses to temperature (and likely moisture) changes by limiting the age and biomass of tree cohorts (Davis and Botkin 1985). Perturbations do not necessarily push these forests beyond their historic range of compositional variability, but instead ensure the dominance of pioneer taxa across a wide range of climatic conditions. The potential role of large, high-severity disturbances in homogenizing and stabilizing the composition of forested landscapes is not clear, however (e.g., Weir et al. 2000), and needs to be understood in the context of future changes in climate and disturbance regimes (Dale et al. 2001).

Here, we hypothesize that severe hydroclimatic changes affected the Rocky Mountain region during the past 17000 years (17 ka [ka stands for thousands of years before the present, defined as AD 1950]), but that regional forests remained highly resilient in the context of these climatic "pushes" because of (1) the broad climatic tolerance of the forest constituents and (2) repeated perturbations that maintained non-steady-state landscapes dominated by pioneer species (Romme and Knight 1982, Romme and Despain 1989, Turner et al. 1993). To test this hypothesis, we evaluate the response of forest composition and fire regimes to past millennialscale, hydroclimatic changes in a subalpine watershed of the Medicine Bow Mountains, southeastern Wyoming, and compare the history of vegetation change to the timing, magnitude, and frequency of ecosystem perturbations including fires and climatic changes. To do so, we reconstruct vegetation and fire history from fossil pollen and sedimentary charcoal data for comparison with an independent reconstruction of the hydroclimatic history based on sedimentary evidence of lake-level change in a small kettle lake. In doing so, we use the 

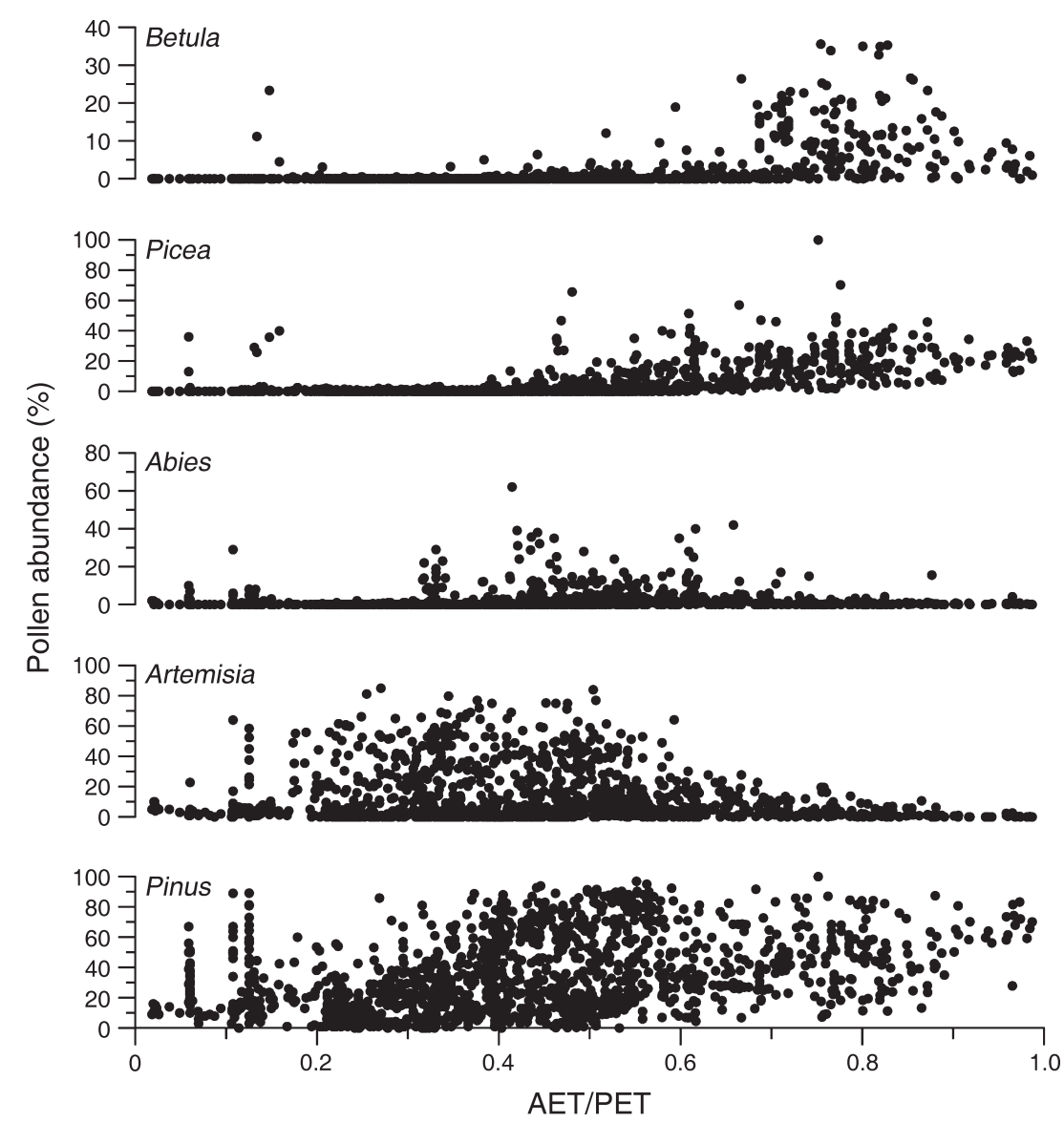

FIG. 1. The relationship of the modern pollen percentage abundance for selected western North America pollen types (relative to all the pollen in a sample) to a moisture index (the ratio actual evapotranspiration to potential evapotranspiration, AET/PET), calculated using the Priestly-Taylor equation (Prentice et al. 1992, Minckley et al. 2008). Pollen types are inclusive of all contributing species in 1514 surface samples from the intermountain West between $30^{\circ}$ to $60^{\circ} \mathrm{N}$ latitude and $100^{\circ}$ to $120.5^{\circ} \mathrm{W}$ longitude (Minckley et al. 2008). The $y$-axes are scaled independently to show maximum variance for each pollen type.

term "effective moisture" to refer to the balance of precipitation and evapotranspiration (P-ET) within our study watershed as represented by the lake-level history; P-ET is linearly related to the ratio of actual to potential evapotranspiration (AET/PET) except when soils are saturated (AET/PET $=1$; Priestley and Taylor 1972).

\section{Study site}

Little Windy Hill Pond (41.432928 ${ }^{\circ}$ N, $106.336342^{\circ} \mathrm{W}$, 2980 m elevation), Carbon County, Wyoming, USA, is a small, groundwater-fed lake (1.32 m deep, 2.2 ha surface area) on the margin of a recessional moraine in the Medicine Bow Mountains with no in-flowing streams and an ephemeral outflow channel (Fig. 2). The watershed itself is small (10.7 ha) with shallow slopes surrounding the lake basin (see Plate 1). Shinker et al. (2010) used preliminary sediment data from Little Windy Hill Pond to calculate past changes in effective moisture of up to $>250 \mathrm{~mm} / \mathrm{yr}$ based on reconstructed changes in lake volume.
The forest surrounding the lake is composed of oldgrowth lodgepole pine (Pinus contorta var. latifolia Engelm. ex Wats.) and Engelmann spruce (Picea engelmannii Parry ex Engelm.), with subdominant subalpine fir (Abies bifolia A. Murray) in the lower canopy. The open understory is comprised of shrubs (Juniperus communis var. depressa Pursh., Artemisia spp., Rosa spp., Ribes spp., and Ericaceae spp.), grasses, and forbs (Poaceae, Asteraceae, and Amaranthaceae). Similar high-elevation subalpine forests in this region experience infrequent, high-severity crown fires as well as large disturbances caused by wind and phytophagus insects (Veblen 2000). These forests represent $46 \%$ of the forested region of the Rocky Mountains, and $91 \%$ of the Medicine Bow Mountains, Wyoming (with 28\% of the area dominated by spruce-fir forest and $63 \%$ by lodgepole pine forest [Dillon et al. 2005]). The thinbarked conifer species are highly susceptible to mortality during fire events (Schoennagel et al. 2004), but post-fire succession favors lodgepole pine and Engelmann spruce initially with subalpine fir abundance increasing as 
A) Little Windy Hill Pond and watershed

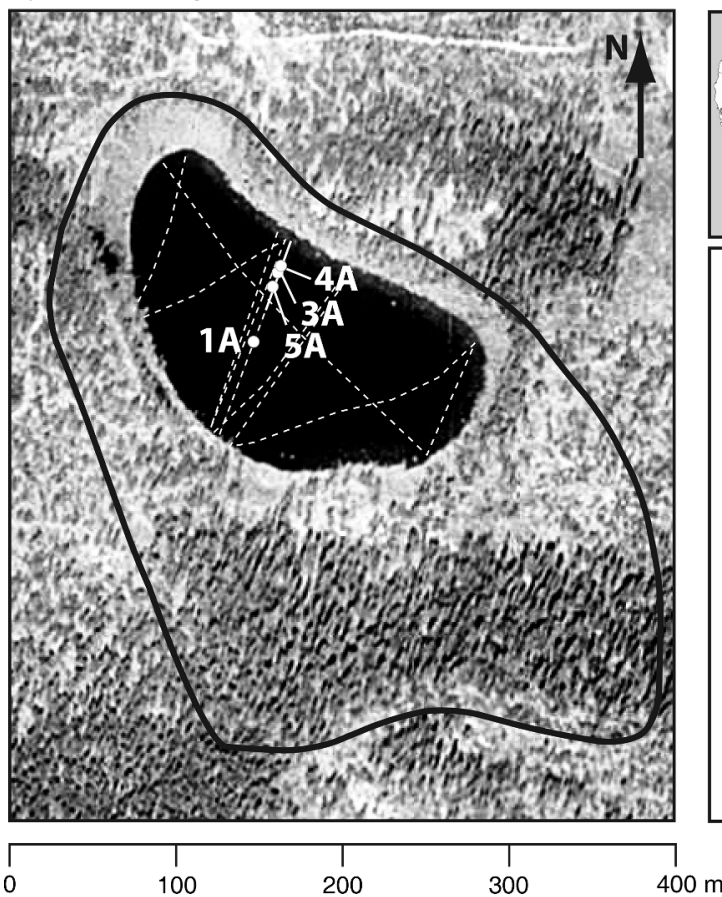

B) Regional location
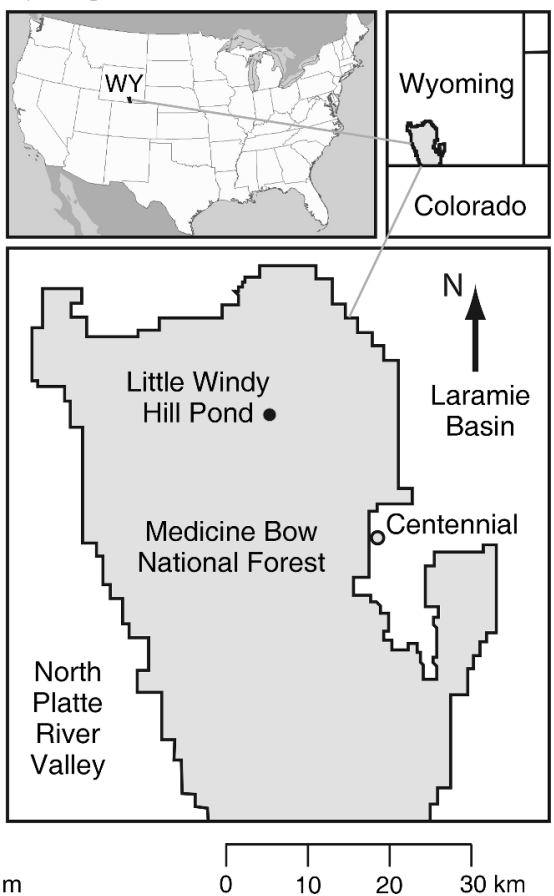

FIG. 2. The Little Windy Hill watershed and location in the Medicine Bow Mountains of southeastern Wyoming, USA. Ten ground-penetrating radar (GPR) transects (dashed lines in panel A) were used to characterize subsurface sediment limits interpreted as past shoreline features, and are shown along with locations of sediment cores (white circles in panel A) collected for this study.

stands mature (Veblen et al. 1991). Wind-throw events, insect outbreaks, and other parasites, however, can lead to different successional trajectories (Baker and Veblen 1990, Kipfmueller and Baker 1998, Kulakowski and Veblen 2003, Kipfmueller and Kupfer 2005, Raffa et al. 2008), and the response to such events can be detected using pollen analyses (Anderson et al. 2010, Minckley and Shriver 2011).

Presently, fire sizes in similar subalpine ecosystems can reach $>150000$ ha, but more commonly individual fires are $<3000$ ha, in part because barriers to spread often limit fire size within small watersheds (Baker and Kipfmueller 2001). High-elevation plateaus with little relief within the Medicine Bow Range and pollen source area of Little Windy Hill Pond, however, could allow for large fires, although topographic barriers may be important near the lake. The rotation time of highseverity fire has been estimated at 225-350 years in subalpine forests of Wyoming and Colorado (Baker 2009), but varies with elevation with $\sim 150-200$ year rotation times in low-elevation lodgepole pine forests and $\sim 400-700$ years in high-elevation spruce-fir forests in northern Colorado (Sibold et al. 2006). Baker (2009) notes that forests in mesic western Colorado have shorter fire-rotations than similar forests in the more xeric eastern slopes of the Colorado Front Range (Howe and Baker 2003, Buechling and Baker 2004, Sibold et al. 2006). Interannual climate variation (i.e., annual drought periods affecting fuel moisture) also strongly influences the severity and frequency of disturbance in these forests (Schoennagel et al. 2005).

Important for paleoecological interpretations, Little Windy Hill Pond likely also receives pollen from the lowelevation $(<2500 \mathrm{~m})$ basins that surround the Medicine Bow Range including the Laramie, Shirley, and Hanna basins, as well as the valley of the North Platte River to the west and North Park, Colorado, to the south. Important plant associations in these basins include mixed-prairie grasslands in the basins to the east and sagebrush-steppe and salt-tolerant desert shrub lands in the basins to the west (Knight 1994). Riparian corridors can be dominated by many genera including Populus, Salix, or Artemisia depending on perennial vs. ephemeral stream flow and local soil salinity (Knight 1994).

\section{Methods \\ Lake-level reconstruction}

To constrain the hydroclimatic history of the Medicine Bow Mountains for comparison with the vegetation history, we reconstructed the past water levels of Little Windy Hill Pond. We followed a well-established approach (Digerfeldt 1986, Shuman et al. 2009, 2010), which depends on the concept that sandy, inorganic sediments tend to accumulate slowly in nearshore (littoral) areas of small lakes and that organic-rich muds accumulate relatively rapidly where water depths exceed $\sim 1 \mathrm{~m}$ (Shuman 2003). Changes in the lateral 
TABLE 1. Sediment core locations, distance from shore, water depth, and core length for Little Windy Hill Pond, Carbon County, Wyoming, USA (cores collected July 2008).

\begin{tabular}{lccccc}
\hline \hline Core & Latitude $\left({ }^{\circ} \mathrm{N}\right)$ & Longitude $\left({ }^{\circ} \mathrm{W}\right)$ & $\begin{array}{c}\text { Distance } \\
\text { from shore }(\mathrm{m})\end{array}$ & $\begin{array}{c}\text { Water } \\
\text { depth }(\mathrm{m})\end{array}$ & Length $(\mathrm{cm})$ \\
\hline 1A & 41.43304 & 106.33724 & 66 & 1.32 & 332 \\
5A & 41.43334 & 106.33709 & 31 & 1.37 & 153 \\
3A & 41.43340 & 106.33707 & 24 & 1.22 & 90 \\
4A & 41.43344 & 106.33704 & 19 & 1.02 & 30 \\
\hline
\end{tabular}

position and elevation of the boundary between sandy littoral sediments and organic lacustrine muds can therefore track changes in shoreline position and water-surface elevation. The boundary between littoral and deeper water sediment types has been widely referred to as the "sediment limit" (Digerfeldt 1986).

By using ground-penetrating radar and transects of sediment cores, we determined the position of the sediment limit, and thus the lake level, through time as an indicator of effective moisture. Layers of sand in our sediment cores are taken to indicate basinward shifts in the sediment limit if they (1) have low net sedimentation rates and (2) are evident around the basin (e.g., appear like "bathtub rings"). Slow net sedimentation rates indicate prolonged accumulation in shallow water where wave action interacts with the substrate, winnows the sediment, and limits rapid accumulation. In contrast, rapid flood events, landslides, or other mechanisms of washing sand into a lake would be associated with high net sedimentation rates, and would tend to be localized rather than encircling the entire lake.

\section{Ground penetrating radar (GPR) surveys}

To image the sediment stratigraphy, we used a Geophysical Survey Systems, Inc. (GSSI, Salem, New Hampshire, USA) SIR-3000 ground-penetrating radar (GPR). The antennae (400 and $200 \mathrm{MHz}$ ) were floated across the lake in a small inflatable raft. Ten transects across the lake were made with the GPR along six lines (each between 105 and $240 \mathrm{~m}$ length) spanning most areas of the lake (Fig. 2).

\section{Sediment coring and analyses}

Sediment core locations were chosen to sample a representative section of the stratigraphy based on the GPR data. A series of four sediment cores were collected from near shore to the center of the lake basin (Table 1) using a modified Livingstone piston corer with individual polycarbonate barrels for each section of core. Polycarbonate barrels were detached from the piston device, capped, and returned to the University of Wyoming for description, subsampling, and analysis.

The sediment stratigraphy of the cores was characterized using gamma-ray attenuation bulk density and magnetic susceptibility measured at $1-\mathrm{cm}$ intervals on a Geotek Multi-Sensor Core Logger at the University of Wyoming (Geotek, Inc., Daventry, Northants, UK). Additionally, the mineral and organic contents of the sediments were approximated using loss-on-ignition
(LOI) analysis (Dean 1974, Shuman 2003). Subsamples $\left(1 \mathrm{~cm}^{3}\right.$ volume) of each core were taken at contiguous 1$\mathrm{cm}$ intervals, dried at $100^{\circ} \mathrm{C}$, and burned at $550^{\circ} \mathrm{C}$. The mass difference between the dried and burned samples was divided by the mass of the dry sample to obtain the percentage of loss on ignition (LOI). Low LOI is typical of sandy littoral sediments; high LOI is found in deeper water settings (Shuman 2003).

\section{Sediment age control}

To obtain the ages of stratigraphic transitions (i.e., from low density, organic-rich muds to high density, sandy littoral sediment) in the cores, we obtained macrofossil charcoal for accelerator mass spectrometry (AMS) radiocarbon analysis. Samples were selected to bracket the major stratigraphic changes in the cores, and thus provide age-depth relationships for each core (Table 2). Ages were calibrated using IntCal09 (Reimer et al. 2009), and we use the standard geological term, kiloannum (ka), to refer to thousands of calibrated years before AD 1950. Intervals of each nearshore core that were not directly dated were assigned ages by linear interpolation between the calibrated AMS dates. For the central core, used for pollen and charcoal analysis, we used repeated overlapping linear regressions through each consecutive set of three calibrated radiocarbon ages. Line segments were joined at the intersection of two overlapping regressions to minimize inflections points in the age-depth relationships, which could cause artificial features in the charcoal analysis (Whitlock and Larsen 2001).

\section{Charcoal and macrofossil analysis}

Charcoal analysis and fire history was based on contiguous $1-\mathrm{cm}^{3}$ samples along the length of the entire core. Samples were soaked in water, allowed to disaggregate, and sieved through 250 - and $125-\mu \mathrm{m}$ screens. The residuals were transferred to a Petri dish, where charcoal and macrobotanical remains $(>125 \mu \mathrm{m})$ were identified to the lowest possible taxonomic level and tallied using a stereo microscope at 25-50x magnification. Charcoal fragments in these size classes derive from local fires (Clark and Patterson 1997, Clark et al. 1998, Gardner and Whitlock 2001, Lynch et al. 2004), which are commonly $\sim 3000$ ha in subalpine Rocky Mountain forests (Baker 2009) and thus may encompass much of the relevant source area for $\sim 70 \%$ of the pollen in our samples ( $\sim 200$ ha; cf. Sugita 1993). 
TABLE 2. Accelerator mass spectrometry (AMS) radiocarbon date determinations for cores $1 \mathrm{~A}, 5 \mathrm{~A}$, and $3 \mathrm{~A}$ used for determining age-depth relationships for Little Windy Hill Pond.

\begin{tabular}{|c|c|c|c|c|c|c|c|c|}
\hline \multirow[b]{2}{*}{ Lab } & \multirow[b]{2}{*}{ Sample no. } & \multirow[b]{2}{*}{ Core } & \multirow[b]{2}{*}{ Depth $(\mathrm{cm})$} & \multirow{2}{*}{$\begin{array}{l}\text { Radiocarbon age } \\
(\mathrm{yr} \mathrm{BP}) \dagger\end{array}$} & \multirow[b]{2}{*}{ SD } & \multicolumn{3}{|c|}{ Calibrated age $(\mathrm{yr} \mathrm{BP}) \dagger$} \\
\hline & & & & & & Maximum & Median & Minimum \\
\hline UCI & 63879 & $1 \mathrm{~A}$ & 53.5 & 1735 & 20 & 1694 & 1651 & 1613 \\
\hline UCI & 58941 & $1 \mathrm{~A}$ & 59.5 & 2270 & 20 & 2341 & 2316 & 2210 \\
\hline UCI & 63880 & $1 \mathrm{~A}$ & 69.5 & 3040 & 20 & 3323 & 3267 & 3218 \\
\hline UCI & 63881 & $1 \mathrm{~A}$ & 91.5 & 4430 & 20 & 5045 & 5010 & 4872 \\
\hline UCI & 58939 & $1 \mathrm{~A}$ & 105.5 & 5160 & 20 & 5928 & 5921 & 5909 \\
\hline UCI & 58940 & $1 \mathrm{~A}$ & 126.5 & 6640 & 25 & 7566 & 7530 & 7506 \\
\hline UCI & 63882 & $1 \mathrm{~A}$ & 172.5 & 8785 & 25 & 9888 & 9799 & 9709 \\
\hline UCI & 58938 & $1 \mathrm{~A}$ & 195 & 9235 & 45 & 10494 & 10401 & 10297 \\
\hline UCI & 63883 & $1 \mathrm{~A}$ & 240.5 & 9700 & 35 & 11198 & 11154 & 11125 \\
\hline UGA & 4602 & $1 \mathrm{~A}$ & 330 & 14200 & 33 & 17444 & 17135 & 17115 \\
\hline UCI & 78239 & $5 \mathrm{~A}$ & 13 & 1345 & 45 & 1306 & 1275 & 1185 \\
\hline UCI & 78240 & $5 \mathrm{~A}$ & 34 & 3545 & 35 & 3890 & 3837 & 3730 \\
\hline UCI & 78241 & $5 \mathrm{~A}$ & 60 & 4885 & 25 & 5643 & 5618 & 5594 \\
\hline UCI & 78238 & $5 \mathrm{~A}$ & 62 & 4955 & 40 & 5724 & 5682 & 5618 \\
\hline UCI & 78237 & $5 \mathrm{~A}$ & 119 & 7130 & 160 & $8156 \S$ & $7955 \S$ & $7793 \S$ \\
\hline UCI & 58935 & $3 \mathrm{~A}$ & 30.5 & 4110 & 50 & $4806^{\circ}$ & 4642 & $4529^{\circ}$ \\
\hline UCI & 58936 & $3 \mathrm{~A}$ & 37.5 & 4480 & 40 & 5281 & 5160 & 5044 \\
\hline UCI & 58937 & $3 \mathrm{~A}$ & 79.5 & 9460 & 30 & 10740 & 10698 & 10609 \\
\hline
\end{tabular}

Notes: Median values were used to calculate continuous age models for each of the cores. Material dated was $>125-\mu \mathrm{m}$ charcoal pieces except as noted.

$\uparrow$ Years before AD 1950.

† Material dated was bulk sediment.

$\S$ Date not used in analysis; inconsistent with stratigraphic position.

Fire history was determined using CharAnalysis (Higuera et al. 2009), which decomposes the time-series of charcoal accumulation rates into two components: (1) the slowly varying background and (2) highly variable peaks in charcoal accumulation rates. The peaks indicate local fire episodes, but their magnitude may not be meaningful (Conedera et al. 2009). To decompose the charcoal record, charcoal concentrations (pieces/ $\mathrm{cm}^{3}$ ) were binned into regular time intervals (19 and 55 yr) and then converted to charcoal accumulation rates (pieces $\mathrm{cm}^{-2} \cdot \mathrm{yr}^{-1}$; binned into 19 - and 55 -yr intervals, respectively) by dividing by the net sedimentation rate $(\mathrm{yr} / \mathrm{cm})$. The two different binning intervals were used to assess the sensitivity of the charcoal analysis to varying sedimentation rates, and based on the highest (19 yr) and median $(55 \mathrm{yr})$ sedimentation rates determined in the age-depth calculations. Given the age-depth relationship, the temporal resolution of the charcoal data ranges from a high of $19 \mathrm{yr} / \mathrm{cm}$ from 11.1 to $10.0 \mathrm{ka}$ to a low of $101 \mathrm{yr} / \mathrm{cm}$ from 2.7 to $1.8 \mathrm{ka}$.

Background charcoal accumulation rates were established based on a 1000-yr lowess smoother, robust to outliers. Peaks in the charcoal accumulation rates were identified using a locally determined threshold based on the 95th percentile of the noise distribution determined by a Gaussian mixture model (Higuera et al. 2009). Inferred fire-episode frequencies were then smoothed over a 1000-yr moving window (Long et al. 1998).

\section{Pollen analysis}

Pollen sampling was conducted every $4-8 \mathrm{~cm}$ on the centermost core (1B), representing a median temporal sampling rate of 220 years (19 years minimum, 788 years maximum). High sampling frequency $(<150$ years between samples) focused on periods of observed change in the pollen record: $11.7-10.4,7.4-7.1$, and $0.8-0.6 \mathrm{ka}$. Pollen samples underwent standard acid-base digestion (Faegri et al. 1989). A minimum of 300 terrestrial pollen grains was tallied for each sample. Pollen percentages were based on relative proportions of each identified taxon to the terrestrial pollen sum.

To measure rates of change in the pollen record, we measured the dissimilarity between every fourth sample (to capture changes that persisted $>500$ years); close sample spacing $(<150$ years between samples) at major transitions decreased the amount of time included in our dissimilarity calculations and thus made our comparison with background rates of change conservative. Dissimilarity was calculated using the squared-chord distance metric, which is weighted to maximize the signal-tonoise ratio among the changes in taxon-specific abundances (Overpeck et al. 1985).

As in all palynological analyses, different pollen types vary in their level of representation of the local plant populations. For example, a small percentage (1-5\%) change in Abies or Picea pollen at Rocky Mountain lakes may be as ecologically important as a large percentage (20-60\%) change in Artemisia or Pinus pollen (Whitlock and Bartlein 1993, Lynch 1996, Fall 1997, Minckley et al. 2008). For a lake the size of Little Windy Hill Pond, the majority of pollen is assumed to be derived locally (within $\sim 200$ ha; Sugita 1993). Within this context, small changes in the abundance of taxa from distant intermontane basins (e.g., Sarcobatus) provide information about valley environments, which may have had a different local climatic history than high-elevation locations near Little Windy Hill Pond. 
A) GPR profile

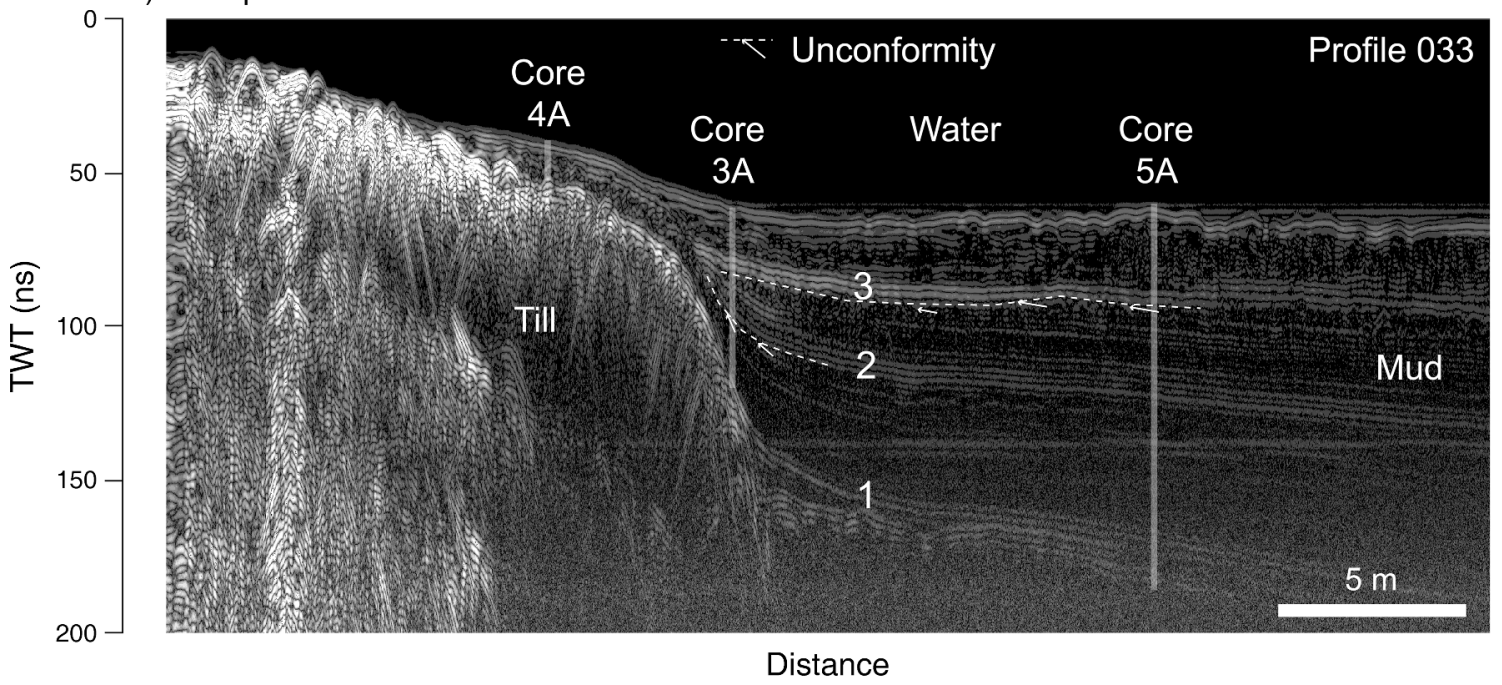

B) Core stratigraphies

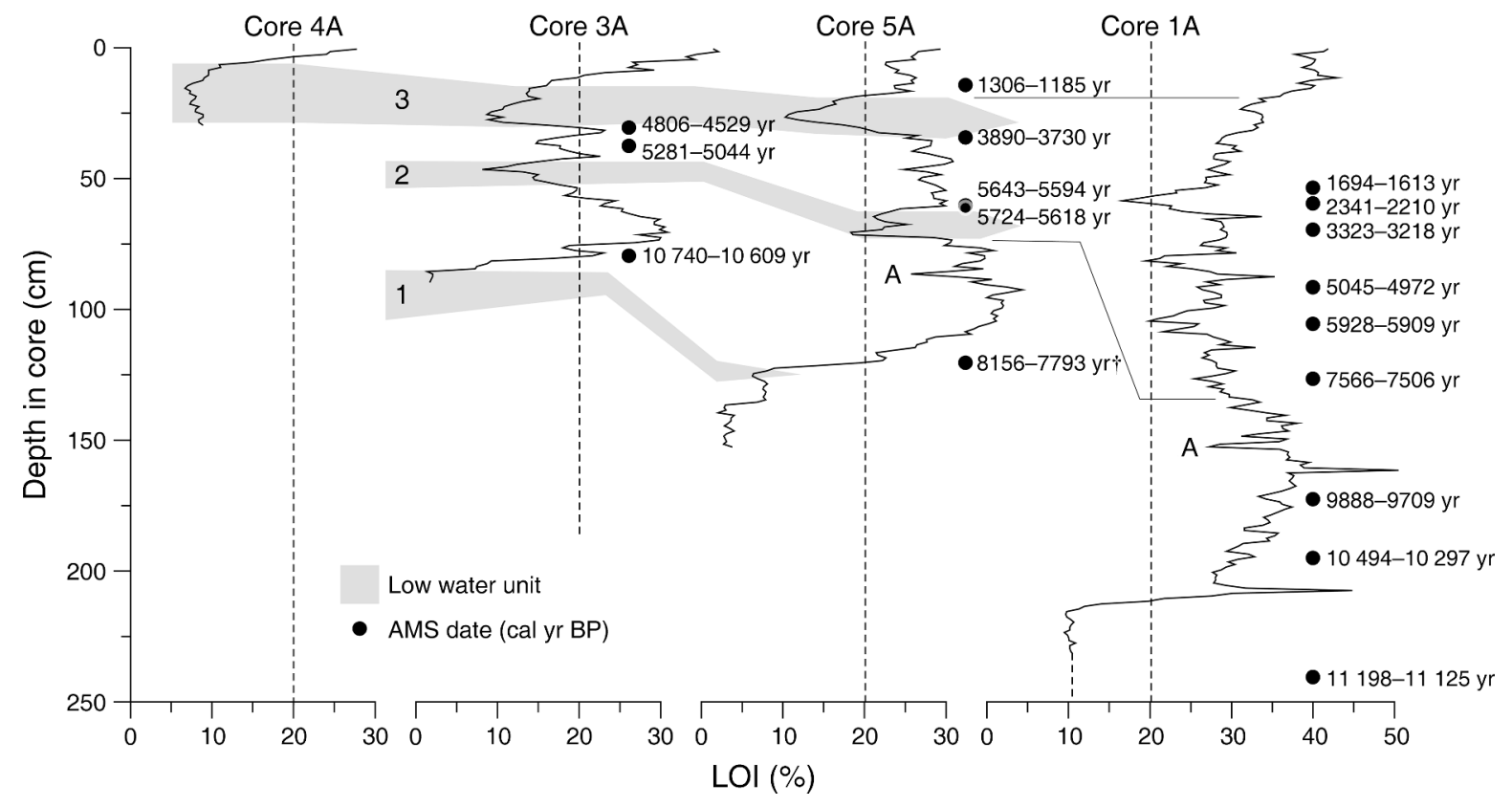

FIG. 3. Ground-penetrating radar (GPR) and sediment core data from Little Windy Hill Pond, Carbon County, Wyoming. (A) GPR data represent a profile through the lake from the north shore toward the center of the lake where the sediment cores (shown as vertical lines) were collected (see core locations and solid white line indicating GPR profile 033 in Fig. 2). GPR data appear relative to two-way travel time (TWT) of the radar signal, which is not linearly related to depth through the profile, but represents approximately $3 \mathrm{~m}$. (B) Sediment loss-on-ignition (LOI) at $550^{\circ} \mathrm{C}$ represents the stratigraphy of each core from shallowest (on left) to deepest (on right). Gray bands indicate the extent of littoral sediment units associated with intervals of low water, and that correlate with reflectors 1-3 and associated unconformities in the GPR data. Solid black circles mark the locations of accelerator mass spectrometry (AMS) radiocarbon dates; maximum and minimum ages listed for each date represent the spread of calibrated ages derived from one standard deviation of the analytical uncertainty. Lines and letters are used to mark correlative features in cores $5 \mathrm{~A}$ and $1 \mathrm{~A}$. The dagger represents a date not used in the analysis.

However, pollen representing different environmental regimes through time likely derive from different pollen source areas (Jacobson and Bradshaw 1981). Generally, the influence of extra-local (intermontane basin) pollen should decrease as local forest density increases (Minckley et al. 2008).

\section{RESUlts}

\section{Lake level and moisture history}

The sediment stratigraphy of Little Windy Hill Pond (Fig. 3) contains evidence of past shifts in the position of the sediment limit (Fig. 4), which we interpret to 

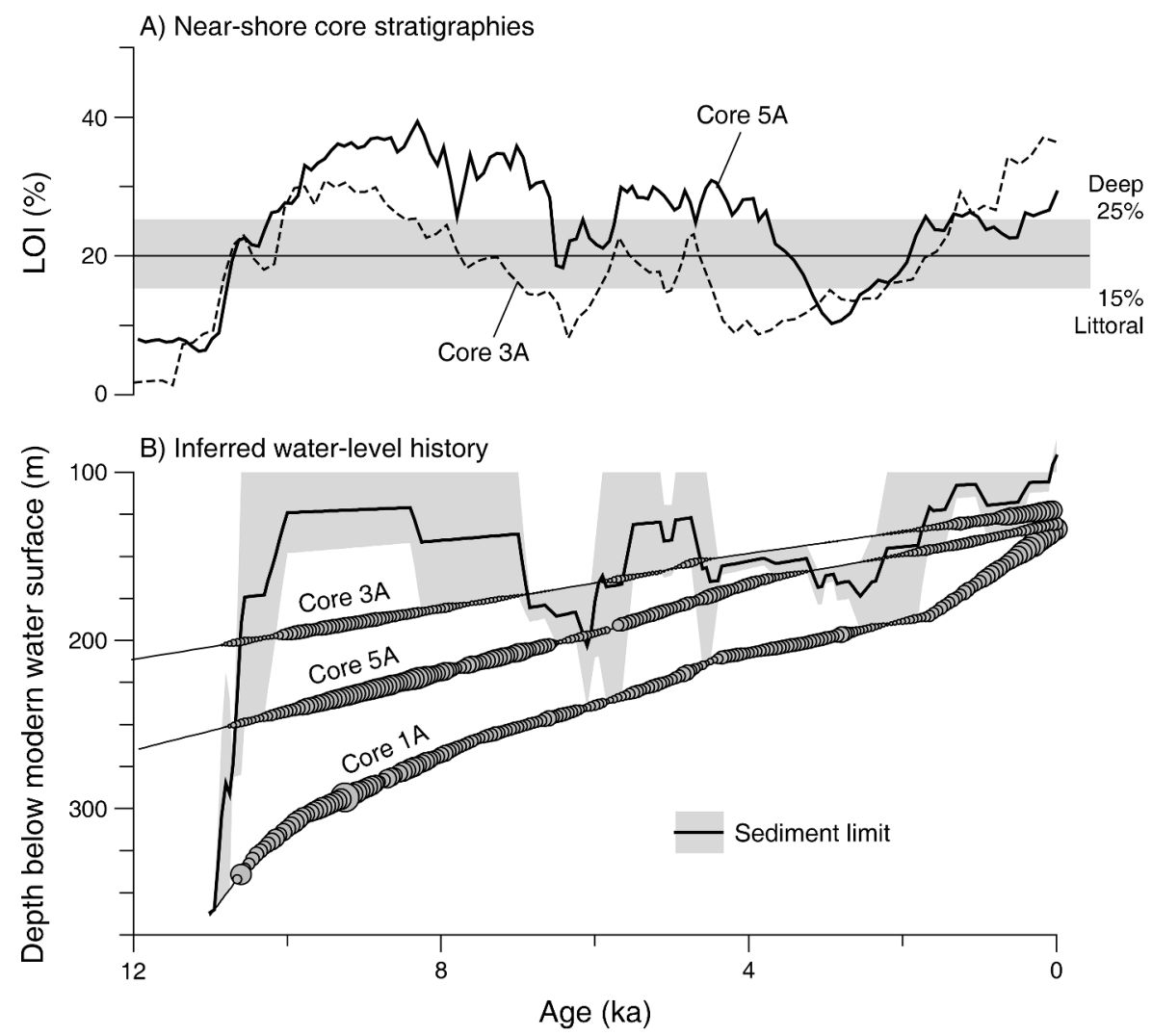

FIG. 4. Core loss-on-ignition (LOI) and age-depth data, and the inferred history of the sediment limit and water level. (A) LOI data for nearshore cores $3 \mathrm{~A}$ (dashed line) and $5 \mathrm{~A}$ (solid line) are plotted with respect to time. The vertical gray bar marks the range from $15 \%$ to $25 \%$, indicative of the transition between deep-water and littoral sediments today; the solid line at $20 \%$ represents the approximate position of the "sediment limit." (B) Core age-depth relationships appear as lines, and circles plotted on the lines denote $1-\mathrm{cm}$ intervals within the core with $>25 \%$ LOI (i.e., deep-water sediments). Circle sizes are scaled to the LOI of the samples and increase in size from dots equal to the line thickness for $25 \%$ LOI to large circles for $50 \%$ or greater LOI. A gray band marks the potential depth range of the transition of 15-25\% LOI in the past, based on a 150-yr moving average of the individual core data, and the assumption that if all cores had $>25 \%$ LOI then the sediment limit could be as high as today. The heavy black line represents the mean depth of the 15-25\% LOI transition zone and indicates the inferred position of the "sediment limit" in the past, which we assume has remained parallel to the water surface, and thus also represents the water-level history. Age is measured in ka (thousands of years before AD 1950).

represent parallel changes in lake level and effective moisture. A lack of organic sediment accumulation in nearshore cores $4 \mathrm{~A}$ and $3 \mathrm{~A}$ before ca. $10.7 \mathrm{ka}$ constrains the initial position of the sediment limit (Fig. 3), and indicates that it was likely $>2 \mathrm{~m}$ below its modern position (Fig. 4). If the sediment limit and water levels had been high, organic-rich silts would have been able to accumulate across the basin, including in the nearshore core locations. GPR profiles confirm a confined area of sediment accumulation prior to the initial accumulation of organic-rich silts in core $3 \mathrm{~A}$, which AMS-dated charcoal fragments from $79-80 \mathrm{~cm}$ depth in the core indicate began at ca. 10.7 ka (Fig. 3). Prior to $10.7 \mathrm{ka}$, sand layers at the base of core $5 \mathrm{~A}$, marked by intervals of near zero LOI and correlating with a prominent reflector (1 in Fig. 3) in GPR profiles, provide evidence of additional early fluctuations in the position of the sediment limit. Potentially, its position fell to a minimum during the Younger Dryas chronozone
(12.9-11.6 ka), based on similar evidence from other sites (e.g., Shuman et al. 2010), but the layers are not directly dated here.

At $10.7 \mathrm{ka}$, LOI in cores $3 \mathrm{~A}$ and $5 \mathrm{~A}$ increased from $<10$ to $>20 \%$ consistent with a rise in the elevation of the sediment limit and a shoreward shift in the littoral zone (Figs. 3, 4). High LOI in the cores after $10.7 \mathrm{ka}$ likely represents a high position of the sediment limit and widespread organic-rich accumulation. We then infer a decline in the elevation of the sediment limit and a basinward shift in the littoral zone from a decrease in the LOI of core $3 \mathrm{~A}$ to $<20 \%$ above $57 \mathrm{~cm}$ depth in the core. The decline likely began by $8.4 \mathrm{ka}$ and continued until $7 \mathrm{ka}$ when the LOI declined abruptly (above $77 \mathrm{~cm}$ depth) in core $5 \mathrm{~A}$, which is dated based on correlative features and ages in core 1A (Figs. 3, 4).

The low LOI sediments dating from $>7 \mathrm{ka}$ to $5.6-5.2$ $\mathrm{ka}$ in cores $3 \mathrm{~A}$ and $5 \mathrm{~A}$ correlate with a prominent reflector (2 in Fig. 3A) and evidence of nearshore 
unconformities (breaks in the constant sediment accumulation) in the GPR data. This inorganic layer likely represents a period when the littoral zone expanded basinward of core $5 \mathrm{~A}$, which would require the sediment limit to have been approximately $1 \mathrm{~m}$ lower than today. Such a change would be the equivalent to $\sim 1 \mathrm{~m}$ decline in water level and potentially a $>200 \mathrm{~mm} / \mathrm{yr}$ reduction in effective moisture across the watershed, which is comparable in magnitude to (but longer in duration than) the most severe historic annual drought in the region (AD 2002; Shinker et al. 2010). The sediment limit then likely rose because organic-rich silts accumulated as far shoreward as core $3 \mathrm{~A}$ from 5.2 to $4.6 \mathrm{ka}$ (Fig. 4). Low water levels then resumed until ca. $1.2 \mathrm{ka}$ based on a subsequent drop in the LOI to $<15 \%$ above $30 \mathrm{~cm}$ depth in both cores $3 \mathrm{~A}$ and $5 \mathrm{~A}$. Reflector 3 in the GPR profile correlates with this uppermost low LOI interval, and truncates underlying nearshore sediments consistent with winnowing and erosion during low water (Fig. 3). The expansion of high-LOI silts shoreward to the location of core $4 \mathrm{~A}$ marks the rise to the modern position of the sediment limit (and water level) after ca. $1.2 \mathrm{ka}$.

\section{Fire history}

Charcoal concentration was low, averaging 3.6 particles $/ \mathrm{cm}^{3}$ prior to $11 \mathrm{ka}$ (Fig. 5). After $11 \mathrm{ka}$ charcoal concentrations increase markedly averaging 11.1 particles $/ \mathrm{cm}^{3}$ prior to a distinct peak (123 particles/ $\mathrm{cm}^{3}$ ) centered on $7.1 \mathrm{ka}$. After this peak, charcoal concentration was slightly higher than before and averaged 16.3 particles $/ \mathrm{cm}^{3}$ until $\sim 1.5 \mathrm{ka}$, when charcoal concentration decreased toward the present (6.4 particles $\left./ \mathrm{cm}^{3}\right)$. Charcoal accumulation rates were low throughout the record, and never exceeded 1 particle $\cdot \mathrm{cm}^{-2} / \mathrm{yr}^{-1}$. Charcoal accumulation rates increased, however, to maxima at 11 to $10 \mathrm{ka}, 8.5$ to 7.5 $\mathrm{ka}$, and near $1.5 \mathrm{ka}$.

Several multi-century ( $>500 \mathrm{yr}$ ) periods contain no evidence of fire episodes based on both the 19- and 55-yr binning of the charcoal time series: 14.1-11.1, 10.0-9.5, 8.6-7.9, 7.2-<6.2, 4.1-3.4, 3.1-2.3, and 2.2-1.6 ka (Fig. $5)$. The frequency of peaks in charcoal accumulation depends, in part, on changes in net sediment accumulation and the binning interval selected, but the fire-free episodes appear regardless of binning intervals and occur across a range of net sedimentation rates, 44-101 $\mathrm{yr} / \mathrm{cm}$.

The highest calculated fire-episode frequencies (three to five episodes per millennium) were based on 19-yr binning intervals for $11.1-8.7 \mathrm{ka}$, when spruce and fir were most abundant, but the frequencies may not have been higher than those reconstructed on average since $8.7 \mathrm{ka}$ (i.e., dashed line in Fig. 5E). If treated as fireepisode return intervals, the $19-\mathrm{yr}$ bin produced return intervals of 131-261 yr, but the 55-yr bin produced intervals of 255-353 yr and likely provides a more robust comparator with the low sedimentation rate interval after $8.7 \mathrm{ka}$. Fire-episode return intervals from $8.7 \mathrm{ka}$ to present had median values of 356 and $359 \mathrm{yr}$, based on the 19- and 55-yr binned analyses respectively. By 8.7 $\mathrm{ka}$, fire-episode frequency declined to $<1$ episode per millennium, but then increased to a peak of nearly 4 episodes per millennium by $\sim 1.5 \mathrm{ka}$.

\section{Vegetation history}

Overview: major phases and periods of change.-The Little Windy Hill Pond pollen record (Fig. 6) shows evidence of three major phases: an early Artemisiadominated zone $(>10.6 \mathrm{ka})$, a Picea-Abies-Pinus zone $(10.6-8.5 \mathrm{ka})$, and a Pinus-dominated zone $(<8.5 \mathrm{ka})$. These three phases can be further subdivided into seven distinct pollen zones (Fig. 6) described in the following subsections, but squared-chord distances ( $\mathrm{SCDs}$ ) measured across adjacent sets of samples reveal that large, rapid change (SCDs $>0.05$ ) only took place at 10.6 and 8.5 ka (Fig. 7). SCDs also peak, indicating additional small changes $(0.03-0.05)$ at $14.0,11.3,10.2,7.2$, and $1.5 \mathrm{ka}$.

Beginning of record to $13.9 \mathrm{ka}$.- High percentages of Artemisia, Cupressaceae (likely Juniperus communis), Rosaceae, Asteraceae, and Poaceae pollen, and low percentages of Picea and Pinus pollen characterize the earliest portion of the record, and indicate an open alpine landscape. Occasional spruce trees may have been locally present, but closed forests had not yet formed around the lake based on the pine pollen percentages of $<20 \%$ (Minckley et al. 2008). Pines were likely lodgepole pine based on the abundance of Pinus subgenus Pinus type pollen.

13.9 to $11.1 \mathrm{ka}$.-From 13.9 to $11.1 \mathrm{ka}$, Cupressaceae, Picea, and Pinus pollen percentages decreased while Artemisia, Amaranthaceae, and Poaceae pollen percentages increased or remained constant. These trends along with a slight increase of Sarcobatus pollen percentages indicate that the regional vegetation was likely more open than before $13.9 \mathrm{ka}$.

11.1-10.6 ka.-This short interval (500 years) shows a rapid transition from open vegetation to woodlands or parkland marked by increases in Abies, Picea, and Pinus pollen percentages, a decrease in Artemisia pollen percentages, and the absence of many other common taxa. Macrobotanical remains show that local populations of fir and spruce had established by $10.8 \mathrm{ka}$. Maximum Betula (possibly B. occidentalis) pollen percentages differentiate this interval from subsequent forest phases (Fig. 6).

10.6-8.5 ka.-By $10.6 \mathrm{ka}$, peak Abies and Picea pollen percentages (3-10\%) and intermediate Pinus pollen percentages $(\sim 40 \%)$ indicate increased forest cover based on comparison with modern pollen-vegetation relationships (Minckley et al. 2008). Spruce and fir likely dominated the forest during this period, but local populations of lodgepole and limber (Pinus flexilis James) pines were probably also present. Artemisia pollen percentages decreased through this interval, 

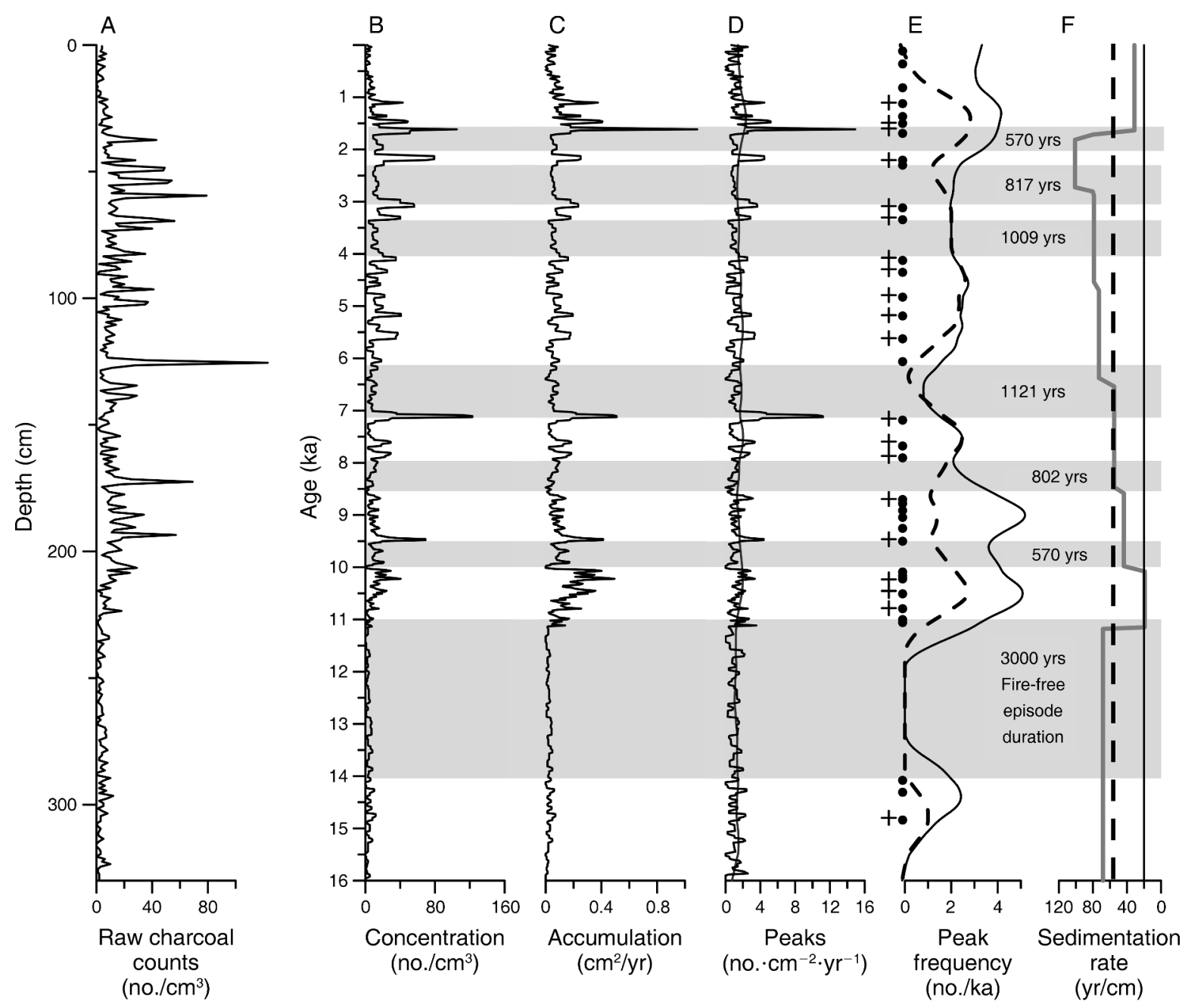

Charcoal

FIG. 5. Decomposition of the Little Windy Hill Pond charcoal data, inferred fire episodes, and summary of fire episode frequency. (A) Concentration of raw charcoal counts plotted by depth. (B) Concentration of raw charcoal counts plotted by time (ka). (C) Charcoal data decomposed into accumulation rates and binned at 19 -year time intervals. (D) Charcoal peak detection based on residuals above a $95 \%$ threshold cutoff of the noise distribution bases on a Gaussian mixture model (Higuera et al. 2009). The smoothed line is the positive threshold of the Gaussian mixture model. Charcoal peaks above the positive threshold are interpreted to constitute fire episodes. (E) Interpreted fire episodes (measured as charcoal peaks) and a summary of the number of fire episodes per millennia for 19-year (circles and solid line) and 55-year (plus symbols and dashed line) binning intervals. (F) Changes in net sedimentation rates (gray line) for core 1A plotted on an inverse scale showing inflection points from the age-depth model. The dashed black line indicates median sedimentation rate $(55 \mathrm{yr} / \mathrm{cm})$ for the entire core; the solid black line marks the maximum rate $(19 \mathrm{yr} / \mathrm{cm})$.

whereas Amaranthaceae pollen abundance reached a peak.

8.5-7.3 ka.-Turnover in forest composition occurred over the 1200 year period between 8.5 and $7.3 \mathrm{ka}$, with decreasing Abies, Picea, and Artemisia pollen percentages and increasing Pinus pollen percentages. The changes likely indicate further closure of the forest canopy and a shift from spruce-fir to pine dominance, which is analogous to moving downward in elevation through the modern Medicine Bow Range (Dillon et al. 2005). Sarcobatus pollen percentages increased and mesic taxa were largely absent, which may indicate changes not only locally but also in the intermontane basins.

7.3-1.4 ka.-Pinus pollen percentages reach a maximum, but vary between $\sim 50-70 \%$. The oldest lodgepole pine needle is observed at $6.5 \mathrm{ka}$, which would be consistent with the presence of a lodgepole-pinedominated forest. Infrequent but consistently present Abies and Picea pollen ( $>2 \%)$ and macrobotanical evidence indicates that these taxa remained as important constituents of the forest community. In fact, Picea pollen percentages rose briefly to $>5 \%$ at ca. 6 and $2 \mathrm{ka}$ (Fig. 7) during two prolonged fire-free periods (Fig. 5). 


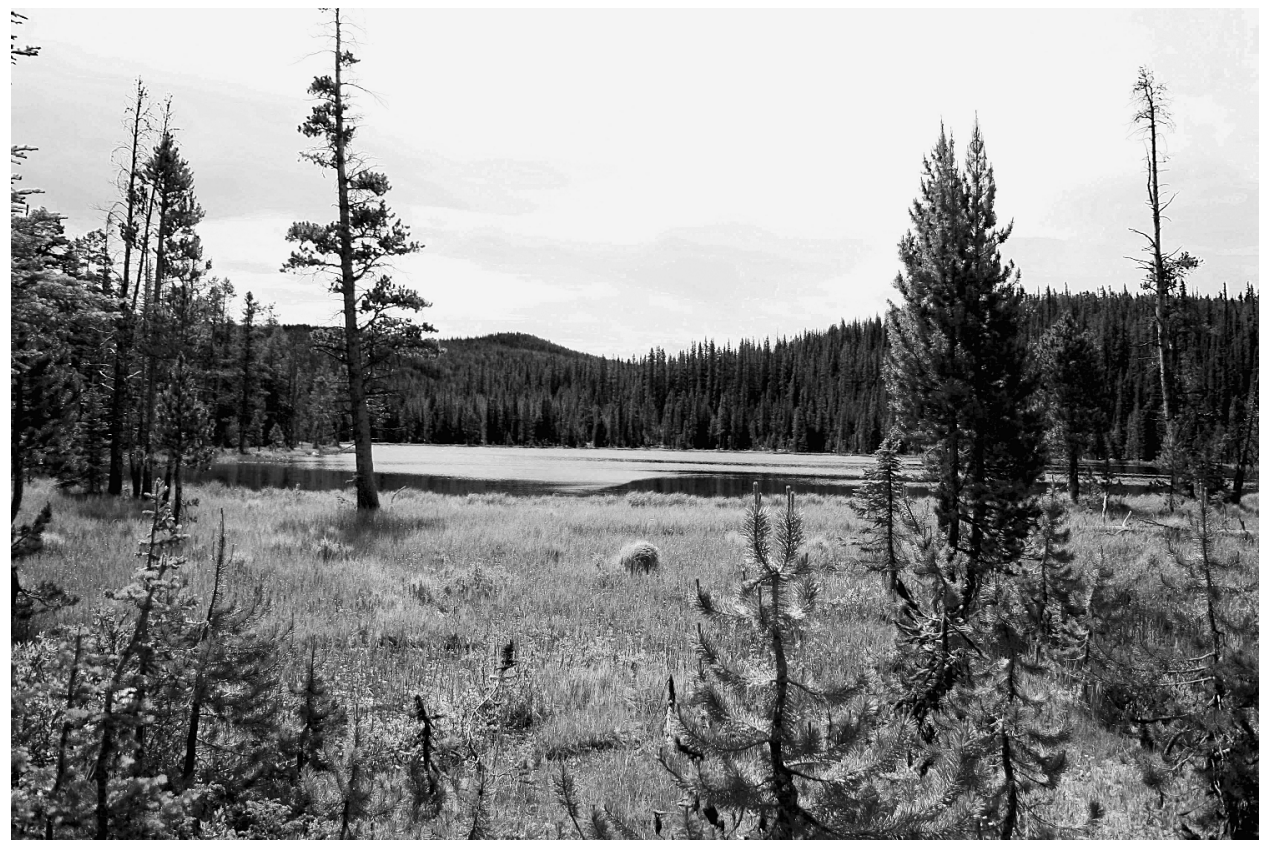

Plate 1. View south toward Little Windy Hill Pond, Carbon County, Wyoming, USA. Sediments in the lake provide evidence that changes in effective moisture over the past 8000 years shifted local fire regimes and caused the water level to fluctuate by $\sim 1 \mathrm{~m}$ but did not shift the local forest composition, which remained in a persistent non-steady state dominated by lodgepole pine. Photo credit: T. A. Minckley.

Artemisa pollen percentages also remain near $\sim 15 \%$, but rise to occasional peaks of up to $25 \%$.

$1.4 \mathrm{ka}$ to present.-Pinus pollen percentages remained high $(>60 \%)$ but were lower than the previous interval. Increased Artemisia pollen percentages $(>20 \%)$ may suggest an opening of the forest environment or a change in the composition of the adjacent basin vegetation.

\section{DisCUSSION}

Comparison of moisture balance and vegetation histories

Lake-level changes coincided with the prominent vegetation changes recorded in the pollen record (Fig. 7), which represent transitions from (1) sagebrush steppe to spruce-fir parkland at ca. $10.7 \mathrm{ka}$ and (2) spruce-fir parkland to pine-dominated forest over the interval from ca. 8.7-7.3 ka (Fig. 5). The inferred moisture balance was probably lowest prior to $10.7 \mathrm{ka}$ when only cores $1 \mathrm{~A}$ and $5 \mathrm{~A}$ accumulated sediment and indicate a smaller lake than exists today or throughout much of the Holocene. The dominance of sagebrush in the pollen record until $10.7 \mathrm{ka}$ is consistent with low effective moisture, inferred from the lake-level evidence, because sagebrush pollen is most abundant today where the moisture index (the ratio of actual evapotranspiration to potential evapotranspiration, AET/PET, calculated using the Preistly-Taylor equation as in Prentice et al. [1992]) is less than 0.5 (Fig. 1). After 10.7 ka, tree pollen representative of spruce-fir parkland became abundant $(>50 \%$ tree pollen), and effective moisture likely increased to levels that were similar to today as indicated by the onset of organic sediment deposition in nearshore core 3A (Fig. 4).

The rise in lake level could represent changes in hydrology as the basin formed and filled with sediment (e.g., Davis and Davis 1980), but the correspondence with vegetation change supports a climatic driver for both phenomena. The rise of Picea and Abies pollen percentages to $>6 \%$ and $2 \%$, respectively, is consistent with high effective moisture because these taxa become abundant above AET/PET values of $>0.4$ (Fig. 1). Because both Abies and Picea pollen tend to be underrepresented relative to Pinus and Artemisia pollen, the observed changes indicate meaningful shifts in forest composition (Minckley et al. 2008). Likewise, the change in lake area (from $<1$ to $>2.5$ ha) probably did not result in a substantial shift in pollen source area that favored tree-pollen deposition (Jacobson and Bradshaw 1981); even very small ponds in sagebrushdominated parks today capture $>50 \%$ tree pollen (e.g., Lynch 1998) and thus have pollen assemblages that differ markedly from those ( $<25 \%$ tree pollen) preserved in the sediments of a small, shallow Little Windy Hill Pond before $10.7 \mathrm{ka}$. Forest-derived paleosols in modern sagebrush steppe in nearby Middle Park, Colorado, also provide consistent regional evidence for expanded forests and high effective moisture from $10.5-9.5 \mathrm{ka}$ (Mayer et al. 2010).

Effective moisture began to fall again between 8.5 and $7.3 \mathrm{ka}$ when sand began to accumulate in cores $3 \mathrm{~A}$ and 


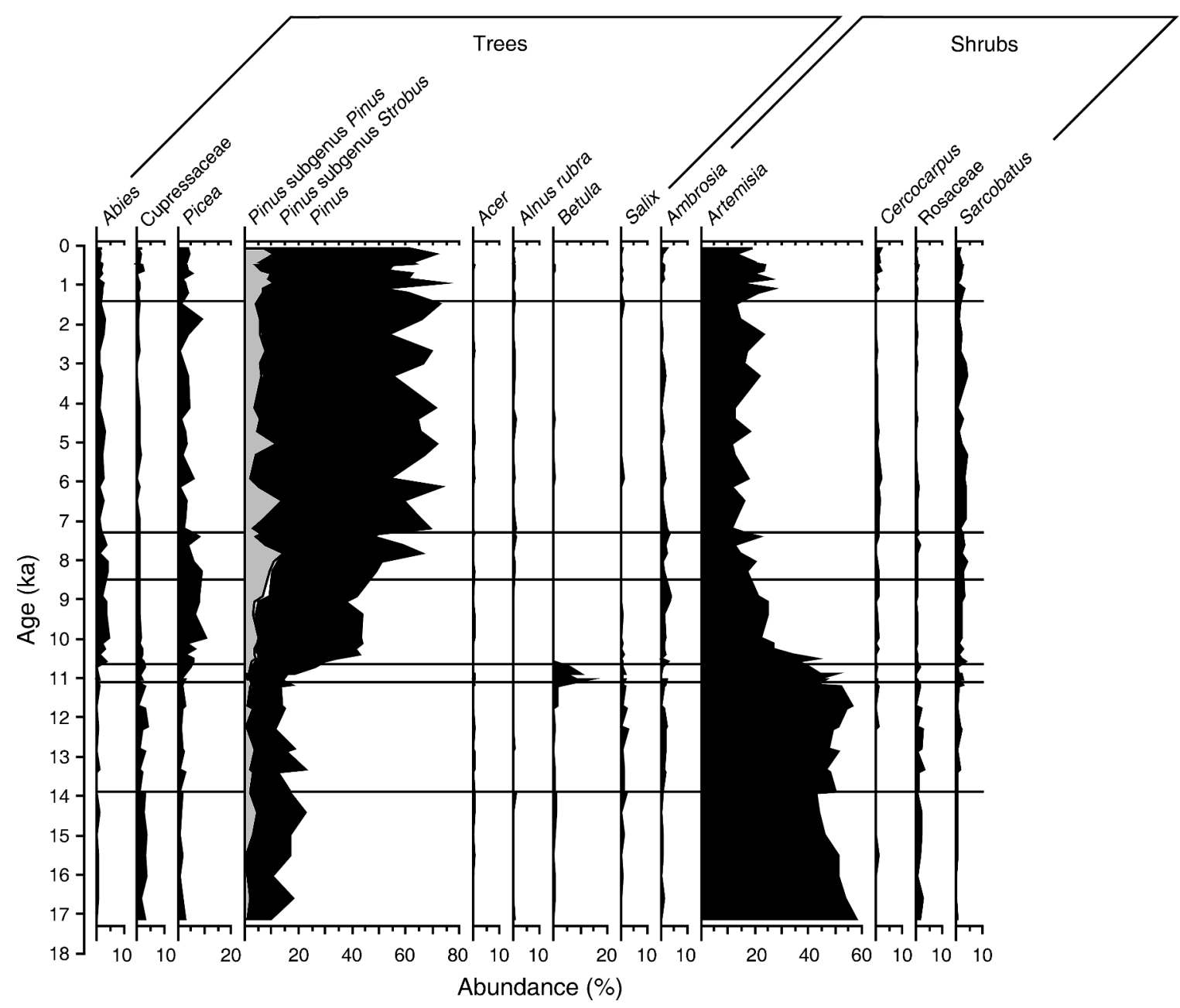

FIG. 6. Pollen percentage diagram for Little Windy Hill Pond Core 1A showing major pollen taxa identified. Percentage abundance ( $x$-axis) shown by time ( $y$-axis). The relative abundance of the trees, shrubs, and forbs was calculated using the sum of taxa placed in those groups. Macrophytes and riparian percentages were calculated on a sum of that group plus the terrestrial taxa. Cluster analysis (CONISS) was used to determine boundaries of significant changes in the pollen assemblages.

$5 \mathrm{~A}$ respectively, marking a basinward shift in the littoral zone of the lake (Figs. 3, 4). Severely low effective moisture $(>100 \mathrm{~mm} / \mathrm{yr}$ lower than today [Shinker et al. 2010]) appears to have been established by ca. $7 \mathrm{ka}$ when the macrofossil and pollen records (including Pinus pollen percentages of $>70 \%$ ) indicate that the vegetation had become a lodgepole pine forest. Today Pinus pollen percentages are high across a broad range of moisture levels, but when Picea and Abies pollen percentages are low $(<5 \%)$, Pinus pollen percentages are high only where AET/PET is $<0.4$ (Fig. 1).

High SCDs at 10.7, 10.2, 8.4, 7.2, and 1.5 ka indicate rapid transitions between vegetation phases, and correspond with large shifts in LOI in the nearshore cores (Figs. 4, 6). For example, a rise and then fall in LOI in the nearshore cores between 10.7 and $7.2 \mathrm{ka}$ appears to track a sequence of rising and then falling lake level and effective moisture (Fig. 4), corresponding with transi- tions into and out of the period of spruce-fir parkland (Fig. 7). Changes in the composition of nearshore sediments also mark a rise in water levels by $5.6 \mathrm{ka}$ and a second decline by $3.7 \mathrm{ka}$ (Fig. 4), which is consistent with evidence for extensive mid-continental aridity from $>7.2$ to $5.6 \mathrm{ka}$ and again at ca. 3.7-2.3 ka (Miao et al. 2007, Shuman et al. 2010).

Changes in effective moisture after $7.2 \mathrm{ka}$, however, do not appear to have generated major vegetation changes (Fig. 7). Lodgepole pine forest was established at the site throughout these episodes, and changed only slightly at $1.5 \mathrm{ka}$ when moderately high SCDs correspond with the rise to modern water levels and a sharp rise in LOI in cores $3 \mathrm{~A}$ and $5 \mathrm{~A}$ (Fig. 7). The continued presence of lodgepole forest after $1.2 \mathrm{ka}$, despite the increased effective moisture, could represent hysteresis within this ecosystem with pine-dominance maintained 


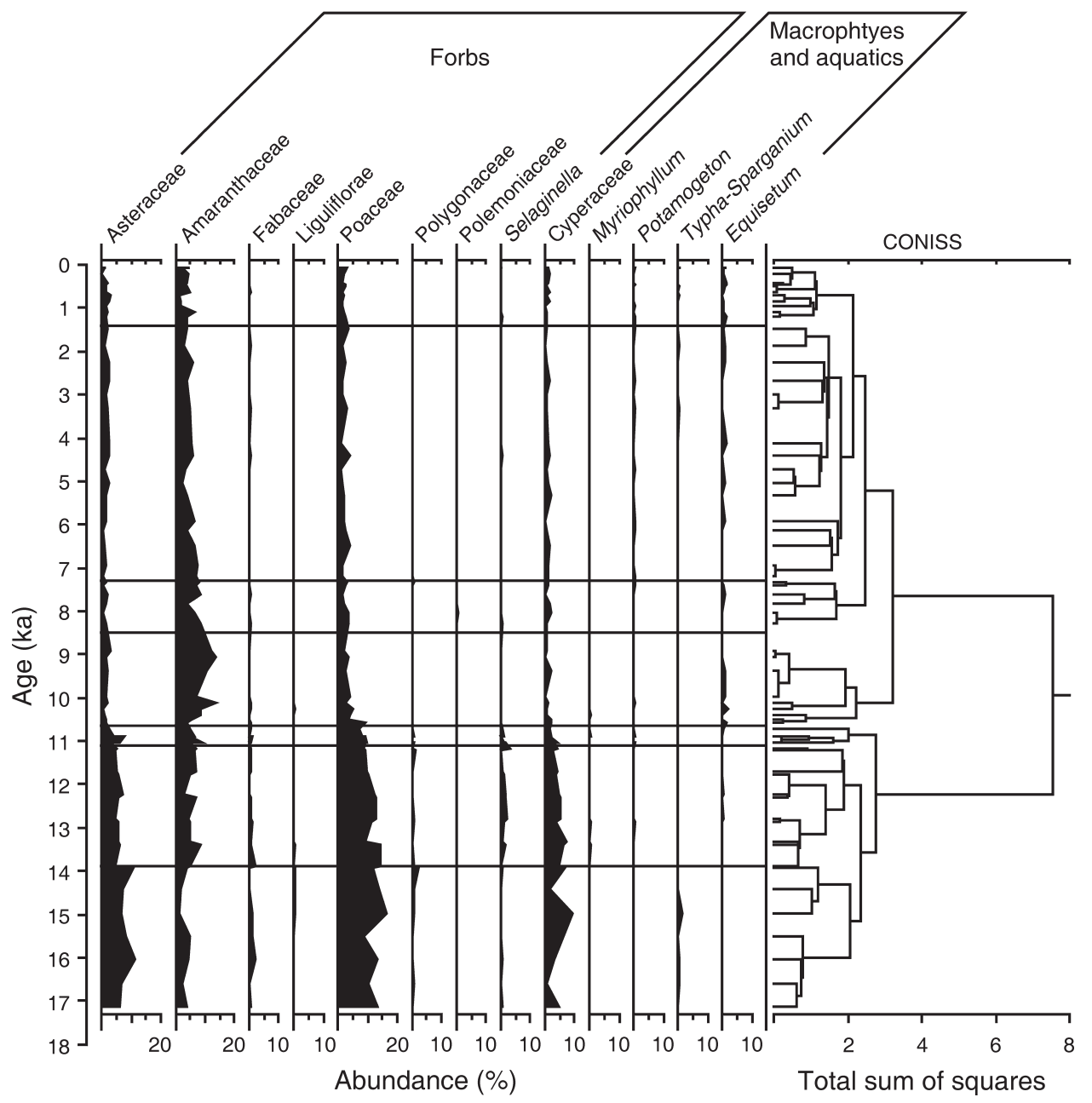

FIG. 6. Continued.

(once established) by high-severity fire regimes (particularly at ca. 1.5-1.0 ka, see Figs. 5, 7).

Based on the magnitude of the LOI changes between 7.2 and $1.5 \mathrm{ka}$, the changes in effective moisture that punctuated the period of lodgepole pine dominance were as large as those that mark the end of the spruce-fir parkland phase (Figs. 4, 7). Indeed, based on the shift in the position of the littoral zone to below core 5A, Shinker et al. (2010) estimated that regional moisture levels were insufficient to sustain permanent flow in the nearby North Platte River; estimates based on other lakes in the region are also consistent with the inference of severely low effective moisture (Shinker et al. 2010, Shuman et al. 2010). Dunes were active in nearby North Park (Ahlbrandt and Andrews 1978), and carbonate soils indicate an upslope shift in the forest-steppe ecotone along the eastern margin of the Medicine Bow range (Reider 1977). Submerged paleoshorelines at Hidden Lake, Colorado, $105 \mathrm{~km}$ to the south, also date to $>4.4 \mathrm{ka}$ and $3.7-1.2 \mathrm{ka}$ (Shuman et al. 2009). The magnitude of these effective-moisture changes might be expected to have produced vegetation responses given the earlier effects of effective moisture levels on local vegetation, but pine pollen percentages simply varied about a mean of $62 \%$ (Figs. 6, 7).

High SCDs at 14.0 and $11.3 \mathrm{ka}$ are not related to documented lake-level changes, but are close in time to well-documented hemispheric temperature changes, including during the Younger Dryas (YD) interval (Reasoner and Jodry 2000, Clark et al. 2001). Peak abundance of Artemisia pollen $(>50 \%)$ during the YD interval may indicate severe aridity, which has been inferred at other lakes in the Rocky Mountains (Stone and Fritz 2006, Shuman et al. 2009, Shuman et al. 2010). Sand layers (low LOI) near the base of core 5A may mark a YD-age low water level at Little Windy Hill Pond, but we were unable to obtain close dates on this event.

A small post-YD rise in water levels may be consistent with high birch pollen percentages at 11.3-10.7 ka (Fig. $6)$. Today, birch pollen is abundant in areas with high AET/PET $(\sim 0.8)$, but can also reach percentages similar 


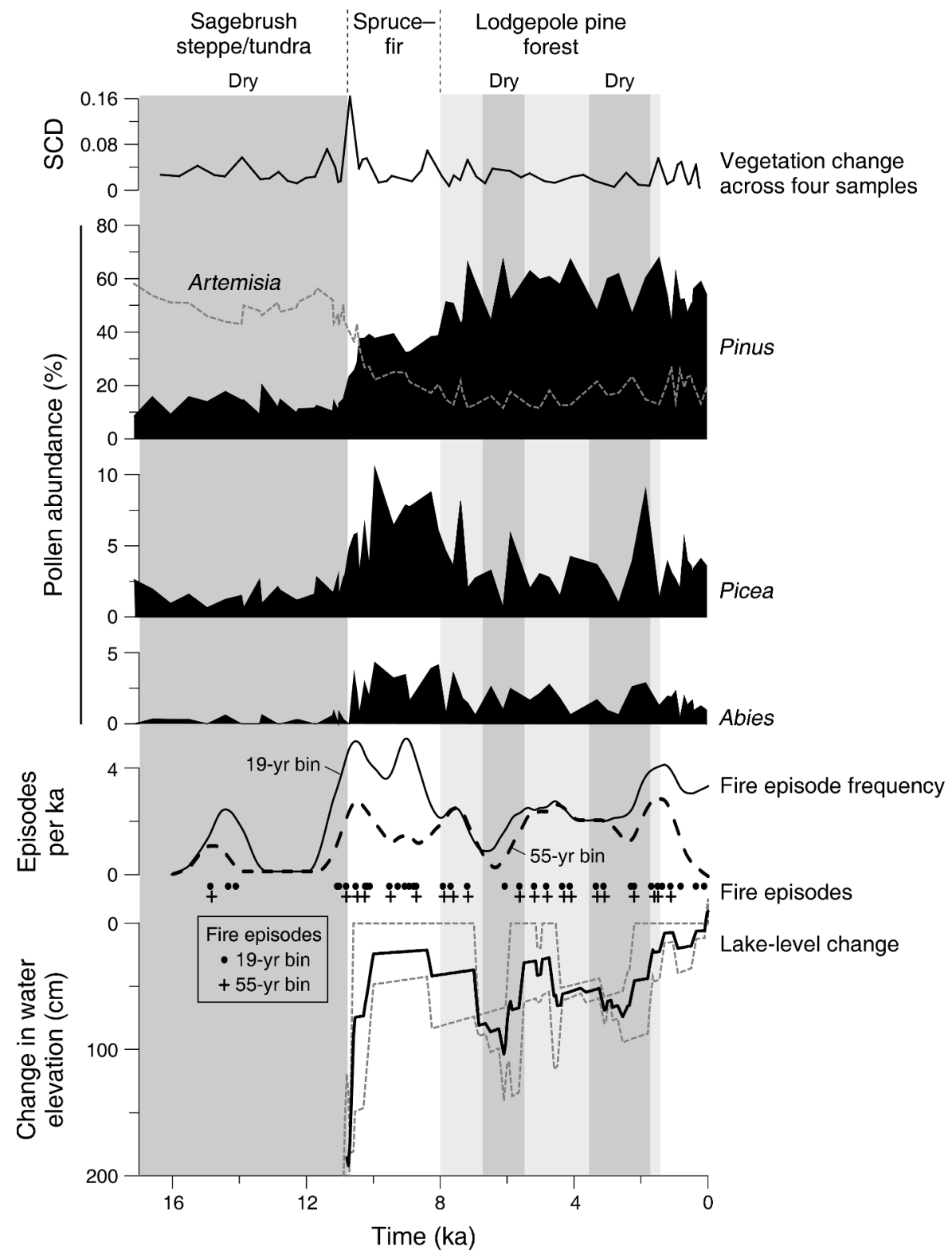

FIG. 7. A summary of the vegetation, fire, and effective moisture history at Little Windy Hill Pond. Squared-chord distances (SCDs) measure the rate of vegetation change through time (top), and capture the major transitions in the pollen data below including the major transitions at 10.7 and ca. $8 \mathrm{ka}$ BP. The frequency of peaks in the sedimentary charcoal record per thousand years (ka) provides a reconstruction of the fire episode frequency (solid line, 19-yr bins; dashed line, 55-year bins); individual fire episodes identified by 19-yr (circles) and 55-yr (crosses) bins show the robustness of peak determination and peak-free periods in the analysis as in Fig. 5. Vertical gray bars denote arid periods, with dark gray representing times when the lake level was sufficiently low for littoral sediments to accumulate in both cores $3 \mathrm{~A}$ and $5 \mathrm{~A}$ (see Fig. 4).

to those in core $1 \mathrm{~A}(>15 \%)$ in areas where AET/PET falls to $<0.6$ (Fig. 1). Because the pollen may indicate the presence of river birch ( $B$. occidentalis), which is presently considered a riparian obligate, the high birch pollen percentages could be consistent with modest expansion of the lake. However, the effect of rising atmospheric $\mathrm{CO}_{2}$ concentrations to $>240$ ppm after the YD (Monnin et al. 2001) may have also improved the water-use efficiency and pollen productivity of local birch populations during this interval, which remained substantially drier than the subsequent 10.7 ka (Fig. 4).

\section{Comparison of fire regime and moisture histories}

Fire, like climate change, was an important source of ecosystem perturbation at Little Windy Hill Pond. Sedimentary charcoal data indicate repeated fire episodes in the watershed throughout the period of record, but also include periods of $>800$ years without major 
fires (Fig. 5). Fire episodes were least frequent during the late-Pleistocene, but increased to two to five episodes per millennium with the development of forests (Fig. 7).

Prior studies in the Rocky Mountains associate increases in fire-episode frequency over millennial scales with periods of warmer- and effectively drier-thanpresent conditions (Millspaugh et al. 2000, Brunelle et al. 2005, Whitlock et al. 2011). We find, however, that fire episodes were most frequent during periods of high water at Little Windy Hill Pond (Fig. 7). As noted by Baker (2009), "this moisture trend is repeated in northern Colorado, where the wetter western slope (Howe and Baker 2003, Sibold et al. 2006) had shorter rotations than the drier eastern slope (Buechling and Baker 2004)." Fire rotation represents the time required for an area equal in size to the landscape of interest to burn, which may be approximated but is not completely constrained by charcoal analyses because of the temporal and spatial resolution of these records (Agee 1993, Whitlock and Larsen 2001, Baker 2009). The temporal resolution of our charcoal record (particularly at ca. 6-2 ka) may lead to overestimating fire rotation when charcoal peaks combine the effects of multiple closely timed fires (e.g., compare fire episodes identified in 19- and 55- year bins in Fig. 5E). The absence of charcoal peaks during several $>800$ year intervals, however, indicates that fires were infrequent during episodes of low effective moisture (e.g., 7-5.6 and 3.7$1.5 \mathrm{ka})$.

Millennial-scale periods of high effective moisture, particularly during the spruce-fir parkland phase from 11.3-8.5 ka, correspond with frequencies of 3-5 fire episodes per millennium. If considered to represent fire rotation periods of $131-261 \mathrm{yr}$, the result is similar to fire rotations documented for recent centuries in lowelevation subalpine forest in northern Colorado: 160-280 yr (Buechling and Baker 2004, Sibold et al. 2006).

In contrast, periods of low effective moisture at Little Windy Hill Pond coincide with the long intervals with no fire episodes (Fig. 7), which may indicate long ( $>800$ yr) fire rotations in both high-elevation steppe before $11.1 \mathrm{ka}$ and subalpine forests at 7.0-5.6 and 3.7-1.5 ka (Fig. 5). Low background charcoal accumulation rates during dry episodes (Fig. 5C) underscore the inferred reduction in fire activity. High-elevation forests in northern Colorado may represent a modern analog to dry intervals at Little Windy Hill Pond because the Colorado forests have historically experienced fire rotations of $\sim 400-700$ years (Sibold et al. 2006), a time scale resolved even at $101 \mathrm{yr}$ per sample.

One explanation for the long intervals ( $>800$ years) between fire episodes during periods of low effective moisture includes the possibility that reduced primary productivity creates low fuel loads and acts to prolong post-fire succession (regeneration). The time frame of successional recovery may lengthen during episodes of low effective moisture because of potential effects of drought on factors such as area burned (Buechling and Baker 2004, Schoennagel et al. 2005), seed dispersal (Turner et al. 1999), serotiny (Schoennagel et al. 2003) and mycorrhizae establishment (Miller et al. 1998).

Intervals of high effective moisture may have experienced more frequent high-severity fires than intervals of low effective moisture because of a complementary interaction between long-term biomass accumulation and interannual climate variability. Dendrochronological and historic data indicate that annual droughts facilitate high-severity fires because of fuel drying in stands that are typically not fuel limited (Schoennagel et al. 2004). Annual and decadal-scale droughts are undoubtedly nested within the millennial scale periods of moisture variation detected in lake records.

\section{Regime shifts}

The pollen and charcoal records from Little Windy Hill Pond indicate at least two major ecosystem regime shifts. The first regime shift marks the transition from sagebrush steppe to spruce-fir parkland at ca. $10.7 \mathrm{ka}$, and was likely both rapid and climate driven (i.e., the system crossed a threshold in the "driver" rather than a threshold in the ecosystem or "state" sensu Andersen et al. 2009). The pollen and charcoal data indicate that both vegetation and fire regimes changed together as effective moisture increased; fires were most frequent from $10.7-10.3 \mathrm{ka}$ during the initial period of parkland establishment, but had been least frequent just prior to development of forests (Fig. 7). The lake-level record indicates that the rise of birch populations prior to 10.7 ka was not the beginning of a gradual transition from open vegetation to parkland, but rather a separate vegetation state associated with less effective moisture than existed after $10.7 \mathrm{ka}$ when the lake expanded. If so, fire, temperature or atmospheric carbon dioxide concentration were likely also a strong control on the vegetation change because birch species are often more abundant in moist regions than spruce and fir (Fig. 1).

The second regime shift (from parkland to lodgepole pine forest by ca. $8 \mathrm{ka}$ ) was also climate driven based on comparison with the lake-level reconstruction. Abrupt ecosystem and climatic changes took place across the region (e.g., Brunelle et al. 2005, Huerta et al. 2009) and the continent at this time because of the collapse of the Laurentide Ice Sheet over Hudson Bay (Shuman et al. 2002, 2006, Williams et al. 2010). The shift in conditions in western North America was also influenced by a change in the state of tropical Pacific (Koutavas et al. 2002, Miao et al. 2007, Barron and Anderson 2011). Just as the birch interval prior to $10.7 \mathrm{ka}$ did not represent a slow transition from steppe to parkland, the spruce-fir parkland does not appear to have been an intermediatestate between steppe and pine forest. Rather, the parkland developed under unusually high levels of effective moisture between two arid phases. The regime shifts between phases were driven by hemispheric climatic changes rather than by local forest dynamics. 


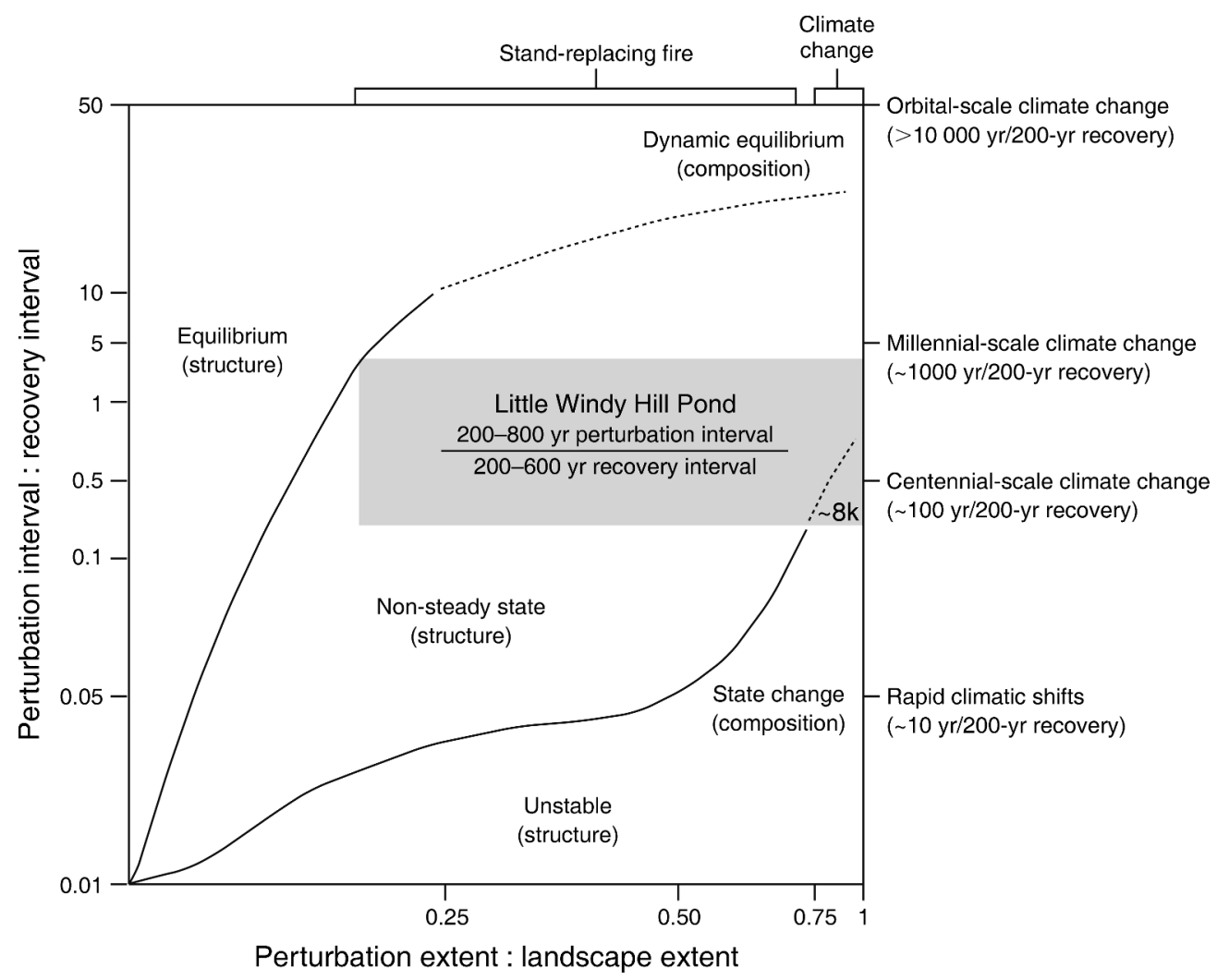

FIG. 8. A conceptual framework for considering the vegetation effects of different frequencies of disturbances and climatic changes ("perturbations") in subalpine forests, such as near Little Windy Hill Pond. The state-space diagram follows from Turner et al.'s (1993) diagram representing disturbance-vegetation interactions but was expanded to incorporate concepts of climatevegetation equilibrium from Webb (1986). The diagram represents the state space determined by temporal and spatial parameters that govern equilibrium: the temporal ratio of perturbation time to recovery interval (used by both Webb [1986] and Turner et al. [1993]) and the spatial ratio of perturbation extent to landscape extent (used by Turner et al. [1993]; Webb [1986] assumes that climate change affects the entire landscape). Different regions within the state space have qualitatively different vegetation dynamics determined by processes such as those noted on the upper and right-hand borders of the figure; boundaries and dynamics within the state space noted by Turner et al. (1993) and Webb (1986) are shown. The gray box marks the position of the Little Windy Hill Pond record within the state space, including the major regime shift at ca. 8 ka.

\section{Resilience and the $>6000$-year persistence of lodgepole pine forests}

In contrast to these regime shifts, and those in other regions (Dean et al. 1984, Shuman et al. 2004, Nelson and $\mathrm{Hu}$ 2008), the regional climate and vegetation histories differed after ca. $8 \mathrm{ka}$ because to the stability of the pine forests. Moisture availability continued to fluctuate, but vegetation type did not. The correlation between lake level and fire-episode frequencies indicates that ecosystem processes (i.e., fire) were responsive to the climatic changes. Variable Pinus pollen percentages during periods when lake levels were low from ca. 8.05.6 and 3.7-1.2 ka suggest that forest composition and structure may have been modestly affected by the climate changes (Fig. 7), but the ecosystem appears to have consistently returned to pine-dominated forest based on the repeated occurrences of $>70 \%$ Pinus pollen.

As proposed by Turner et al. (1993), repeated fire episodes may generate a highly variable, non-steady state pine forest with fires disturbing the ecosystem at or before the time of successional maturation. Numerous fires could readily facilitate a structurally diverse landscape within the pollen source area (Turner et al. 1993). By doing so, fires may prohibit the development of forests dominated by late-successional taxa, such as spruce and fir (Romme and Knight 1981), and thus minimize compositional changes associated with the moisture balance changes of the Holocene. Consistent with this idea of succession, long fire-free intervals (7.2 to $<6.1,4.1-3.4$ and $2.2-1.6 \mathrm{ka}$ ) during episodes of low effective moisture appear to have favored short-lived increases of late-succession spruce populations ca. 5.9, 4.1-3.3, and 1.9 ka (Fig. 7). Picea pollen percentages declined, however, after subsequent fire episodes and effective moisture increased. Such brief persistence of high spruce abundance in the forest surrounding Little Windy Hill Pond compares well with simulated variability of forests disturbed on this time scale (Turner et al. 1993, Schoennagel et al. 2006), and indicates that an 
interaction between fire regimes and climatic conditions facilitated pine dominance over the last 8000 years. High moisture availability prior to ca. $8 \mathrm{ka}$ favored spruce-fir communities, even in the presence of frequent fire (which had an unknown level of severity). Low moisture availability after $8 \mathrm{ka}$, however, does not appear to have prohibited abundant spruce and fir except in combination with frequent fire (Fig. 7).

The time scales of perturbation and recovery in the lodgepole pine ecosystem around Little Windy Hill Pond, thus, favored persistent disequilibrium after ca. $7.3 \mathrm{ka}$ (Fig. 8). The landscape was more often perturbed by fires, drought, and other disturbances than required to allow the ecosystem to reach compositional equilibrium with the varied climatic conditions. This equilibrium state could have included more abundant spruce and fir than observed for much of the past $8 \mathrm{ka}$ based on the increases in Picea and Abies pollen abundances during fire-free intervals (Fig. 7). Given the large spatial scale of both climatic shifts and fires in lodgepole forests, the ratio of perturbation area to the area of the landscape represented by the fossil pollen was high ( $\sim 3000: 200$ ha based on a common high-severity fire size and the "relevant pollen source area" of Little Windy Hill Pond; Sugita 1994, Baker and Kipfmueller 2001). Likewise, given that either fires or climatic shifts took place every $200-500$ years, the ratio of perturbation time to recovery time in forests with 200-600 years of succession (e.g., Romme and Knight 1981, Kipfmueller and Baker 1998, Kashian et al. 2005) was close to 1 . Both of these spatial and temporal perturbation-to-recovery ratios fit well with the frameworks proposed for non-steady state ecosystems (Fig. 8) (Webb 1986, Turner et al. 1993). The system may not have reached a steady state, but was highly resilient and remained within a similar "disequilibrium" regime for $8 \mathrm{ka}$.

The lack of correspondence between vegetation and climatic change during the lodgepole pine phase, therefore, suggests that such systems may be resilient and will recover despite current climate changes favoring widespread disturbance in Rocky Mountain forests (e.g., Westerling et al. 2003, Brown et al. 2010), the composition of such systems may recover through succession dynamics over the next few decades to centuries. Disturbances are changing the structure of Rocky Mountain forests dramatically, but the structure may never have reached a stable state in 8000 years. Alternatively, the rapid regime changes in our record indicate that when climatic changes are sufficiently large to cross species' climatic limits (e.g., Fig. 1), successional pathways can change and new forest composition can develop. Given the projected magnitude of future regional climate change (IPCC 2007) such a regime change may indeed be possible (Jackson et al. 2009).

\section{Conclusions}

Regime changes in Rocky Mountain ecosystems appear to have been driven by large, millennial scale climatic changes, which affected regional moisture availability. However, broad climatic niches and repeated disturbances associated with important regional forest taxa have also facilitated resilient ecosystems. Repeated severe fires and other disturbances, including drought and abrupt climatic shifts, appear to maintain ecosystem composition by re-establishing early-successional trajectories. Our results indicate that highly disturbed ecosystems may be less likely than undisturbed ecosystems to experience long-term composition changes in the face of ongoing and future climatic change.

\section{ACKNOWLEDGMENTS}

The project was supported by Wyoming Water Development Commission and U.S. Geological Survey grants to T. Minckley and B. Shuman, as well as an NSF CAREER grant (BCS0845129) to B. Shuman. R. K. Shriver received support through the University of Wyoming NSF EPSCoR undergraduate research fellowship program. T. Minckley and B. Shuman collaborated on study design, manuscript writing, and data analysis; T. Minckley generated the pollen data, R. Shriver the charcoal data, and B. Shuman the lake-level reconstruction. We thank A. K. Henderson for field assistance, and G. Carter, D. Hougardy, and P. Pribyl for lab analyses. We appreciate the thoughtful and critical reviews by $\mathrm{P}$. Higuera and one anonymous reviewer.

\section{Literature Cited}

Agee, J. K. 1993. Fire ecology of Pacific Northwest forests. Island Press, Washington, D.C., USA.

Ahlbrandt, T. S., and S. Andrews. 1978. Distinctive sedimentary features of cold-climate eolian deposits, North Park, Colorado. Palaeogeography Palaeoclimatology Palaeoecology 25:327-351.

Anderson, P. M., and L. B. Brubaker. 1994. Vegetation history of northcentral Alaska: a mapped summary of late-quaternary pollen data. Quaternary Science Reviews 13:71-92.

Anderson, R. S., S. J. Smith, A. M. Lynch, and B. W. Geils. 2010. The pollen record of a 20th century spruce beetle (Dendroctonus rufipennis) outbreak in a Colorado subalpine forest, USA. Forest Ecology and Management 260:448-455.

Andersen, T., J. Carstensen, E. Hernandez-Garcia, and C. M. Duarte. 2009. Ecological thresholds and regime shifts: approaches to identification. Trends in Ecology and Evolution 24:49-57.

Baker, R. G. 1983. Holocene vegetational history of the western United States. Pages 109-127 in H. E. Wright, editor. LateQuaternary environments of the United States. Longman, London, UK.

Baker, W. L. 2009. Fire ecology in Rocky Mountain landscapes. Island Press, Washington, D.C., USA.

Baker, W. L., and K. F. Kipfmueller. 2001. Spatial ecology of pre-Euro-American fires in a southern rocky mountain subalpine forest landscape. Professional Geographer 53:248-262.

Baker, W. L., and T. T. Veblen. 1990. Spruce beetles and fires in the 19th century sub-alpine forests of western Colorado, USA. Arctic and Alpine Research 22:65-80.

Barron, J. A., and L. Anderson. 2011. Enhanced Late Holocene ENSO/PDO expression along the margins of the eastern North Pacific. Quaternary International 235:3-12.

Breshears, D. D., et al. 2005. Regional vegetation die-off in response to global-change-type drought. Proceedings of the National Academy of Sciences USA 102:15144-15148.

Brown, M., T. A. Black, Z. Nesic, V. N. Foord, D. L. Spittlehouse, A. L. Fredeen, N. J. Grant, P. J. Burton, and J. A. Trofymow. 2010. Impact of mountain pine beetle on the net ecosystem production of lodgepole pine stands in British 
Columbia. Agricultural and Forest Meteorology 150:254264.

Brunelle, A., and C. Whitlock. 2003. Postglacial fire, vegetation, and climate history in the Clearwater Range, Northern Idaho, USA. Quaternary Research 60:307-318.

Brunelle, A., C. Whitlock, P. Bartlein, and K. Kipfmueller. 2005. Holocene fire and vegetation along environmental gradients in the Northern Rocky Mountains. Quaternary Science Reviews 24:2281-2300.

Buechling, A., and W. L. Baker. 2004. A fire history from tree rings in a high-elevation forest of Rocky Mountain National Park. Canadian Journal of Forest Research 34:1259-1273.

Clark, J. S., J. Lynch, B. J. Stocks, and J. G. Goldammer. 1998. Relationships between charcoal particles in air and sediments in west-central Siberia. Holocene 8:19-29.

Clark, J. S., and W. A. Patterson. 1997. Background and local charcoal in sediments: scales of fire evidence in the palaeorecord. Pages 23-49 in J. S. Clark, H. Cachier, J. G. Goldammer, and B. Stocks, editors. Sediments records of biomass burning and global change. NATO ASI Series. Springer-Verlag, Berlin, Germany.

Clark, P. U., S. J. Marshall, G. K. C. Clarke, S. W. Hostetler, J. M. Licciardi, and J. T. Teller. 2001. Freshwater forcing of abrupt climate change during the last glaciation. Science 293:283-287.

Conedera, M., W. Tinner, C. Neff, M. Meurer, A. F. Dickens, and P. Krebs. 2009. Reconstructing past fire regimes: methods, applications, and relevance to fire management and conservation. Quaternary Science Reviews 28:555-576.

Dale, V. H., et al. 2001. Climate change and forest disturbances. BioScience 51:723-734.

Davis, M. B. 1969. Climatic changes in southern Connecticut recorded by pollen deposition at Rogers Lake. Ecology 50:409-422.

Davis, M. B., and D. B. Botkin. 1985. Sensitivity of cooltemperate forests and their fossil pollen record to rapid temperature change. Quaternary Research 23:327-340.

Davis, P. T., and R. B. Davis. 1980. Interpretation of minimum-limiting radiocarbon dates for deglaciation of Mount Katahdin area, Maine. Geology 8:396-400.

Dean, W. E. 1974. Determination of carbonate and organicmatter in calcareous sediments and sedimentary-rocks by loss on ignition-comparison with other methods. Journal of Sedimentary Petrology 44:242-248.

Dean, W. E., J. P. Bradbury, R. Y. Anderson, and C. W. Barnosky. 1984. The variability of Holocene climate change-evidence from varved lake-sediments. Science 226:1191-1194.

Deevey, E. S. J. 1939. Studies on Connecticut lake sediments I. A postglacial climatic chronology for southern New England. American Journal of Science 237:691-724.

Despain, D. G. 1983. Nonpyrogenous climax lodgepole pine communities in Yellowstone National Park. Ecology 64:231234.

Digerfeldt, G. 1986. Studies of past lake-level fluctuations. Pages 247-272 in B. E. Berglund, editor. Handbook of Holocene palaeoecology and palaeohydrology. John Wiley and Sons, New York, USA.

Dillon, G. K., D. H. Knight, and C. B. Meyer. 2005. Historic range of variability for upland vegetation in the Medicine Bow National Forest, Wyoming. General Technical Report RMRS-GTR-139. U.S. Department of Agriculture, Forest Service, Rocky Mountain Research Station, Fort Collins, Colorado, USA.

Faegri, K., P. E. Kaland, and K. Kzywinski. 1989. Textbook of pollen analysis. Wiley, New York, New York, USA.

Fagre, D. B., et al. 2009. Thresholds of climate change in ecosystems: synthesis and assessment product 4.2. U.S. Geological Survey, Reston, Virginia, USA.

Fall, P. L. 1997. Fire history and composition of the subalpine forest of western Colorado during the Holocene. Journal of Biogeography 24:309-325.
Gardner, J. J., and C. Whitlock. 2001. Charcoal accumulation following a recent fire in the Cascade Range, northwestern USA, and its relevance for fire-history studies. Holocene 11:541-549.

Gaudreau, D. C., and T. Webb III. 1985. Late-Quaternary pollen stratigraphy and isochrone maps for the northeastern United States. Pages 247-280 in V. M. Bryant and R. G. Holloway, editors. Pollen records of Late-Quarternary North American sediments. American Association of Stratigraphic Palynologists Foundation, Dallas, Texas, USA.

Green, D. G. 1982. Fire and stability in the post-glacial forests of southwest Nova Scotia. Journal of Biogeography 9:29-40.

Grimm, E. C., and G. L. Jacobson. 1992. Fossil-pollen evidence for abrupt climate changes during the past 18000 years in eastern North America. Climate Dynamics 6:179-184.

Higuera, P. E., L. B. Brubaker, P. M. Anderson, F. S. Hu, and T. A. Brown. 2009. Vegetation mediated the impacts of postglacial climate change on fire regimes in the south-central Brooks Range, Alaska. Ecological Monographs 79:201-219.

Howe, E., and W. L. Baker. 2003. Landscape heterogeneity and disturbance interactions in a subalpine watershed in northern Colorado, USA. Annals of the Association of American Geographers 93:797-813.

Huerta, M. A., C. Whitlock, and J. Yale. 2009. Holocene vegetation-fire-climate linkages in northern Yellowstone National Park, USA. Palaeogeography Palaeoclimatology Palaeoecology 271:170-181.

Huntley, B., and H. J. B. Birks. 1983. An atlas of past and present pollen maps for Europe: 0-13000 years ago. Cambridge University Press, Cambridge, UK.

Huntley, B., and T. Webb III. 1989. Migration: species' response to climatic variations caused by changes in the Earth's orbit. Journal of Biogeography 16:5-19.

IPCC. 2007. Climate change 2007: synthesis report. Contribution of Working Groups I, II and III to the Fourth Assessment Report of the Intergovernmental Panel on Climate Change. IPCC, Geneva, Switzerland.

Jackson, S. T., S. T. Gray, and B. Shuman. 2009. Paleoecology and resource management in a dynamic landscape: case studies from the Rocky Mountain headwaters. Pages 61-80 in G. P. Dietl and K. W. Flessa. Conservation paleobiology. Paleontological Society, Ithaca, New York, USA.

Jackson, S. T., and J. T. Overpeck. 2000. Responses of plant populations and communities to environmental changes of the late Quaternary. Paleobiology 26:194-220.

Jacobson, G. L., and R. H. W. Bradshaw. 1981. The selection of sites for paleovegetational studies. Quaternary Research 16:80-96.

Jacobson, G. L., and E. C. Grimm. 1986. A numerical analysis of Holocene forest and prairie vegetation in central Minnesota. Ecology 67:958-966.

Kashian, D. M., M. G. Turner, W. H. Romme, and C. G. Lorimer. 2005. Variability and convergence in stand structural development on a fire-dominated subalpine landscape. Ecology 86:643-654.

Kipfmueller, K. F., and W. L. Baker. 1998. Fires and dwarf mistletoe in a Rocky Mountain lodgepole pine ecosystem. Forest Ecology and Management 108:77-84.

Kipfmueller, K. F., and J. A. Kupfer. 2005. Complexity of successional pathways in subalpine forests of the SelwayBitterroot Wilderness Area. Annals of the Association of American Geographers 95:495-510.

Knight, D. H. 1994. Mountains and plains: the ecology of Wyoming landscapes. Yale University, New Haven, Connecticut, USA.

Koutavas, A., J. Lynch-Stieglitz, T. M. Marchitto, and J. P. Sachs. 2002. El Niño-like pattern in ice age tropical Pacific sea surface temperature. Science 297:226-230.

Kulakowski, D., and T. T. Veblen. 2003. Subalpine forest development following a blowdown in the Mount Zirkel Wilderness, Colorado. Journal of Vegetation Science 14:653660 . 
Long, C. J., C. Whitlock, P. J. Bartlein, and S. H. Millspaugh. 1998. A 9000-year fire history from the Oregon Coast Range, based on a high-resolution charcoal study. Canadian Journal of Forest Research 28:774-787.

Lynch, E. A. 1996. The ability of pollen from small lakes and ponds to sense fine-scale vegetation patterns in the Central Rocky Mountains, USA. Review of Palaeobotany and Palynology 94:197-210.

Lynch, E. A. 1998. Origin of a park-forest vegetation mosaic in the Wind River Range, Wyoming. Ecology 79:1320-1338.

Lynch, J. A., J. S. Clark, and B. J. Stocks. 2004. Charcoal production, dispersal, and deposition from the Fort Providence experimental fire: interpreting fire regimes from charcoal records in boreal forests. Canadian Journal of Forest Research 34:1642-1656.

Lytle, D. E. 2005. Palaeoecological evidence of state shifts between forest and barrens on a Michigan sand plain, USA. Holocene 15:821-836.

Macdonald, G. M. 1989. Postglacial paleoecology of the subalpine forest-grassland ecotone of southwestern Alberta - new insights on vegetation and climate change in the Canadian Rocky Mountains and adjacent foothills. Palaeogeography Palaeoclimatology Palaeoecology 73:155-173.

Maenza-Gmelch, T. E. 1997. Holocene vegetation, climate, and fire history of the Hudson Highlands, southeastern New York, USA. Holocene 7:25-37.

Mayer, J. H., and S. A. Mahan. 2004. Late Quaternary stratigraphy and geochronology of the western Killpecker Dunes, Wyoming, USA. Quaternary Research 61:72-84.

Mayer, J. H., R. G. Reider, and M. Kornfeld. 2010. The geoarchaeological and paleoenvironmental context of paleoindian sites in western Middle Park, Colorado, USA. Geoarchaeology — an International Journal 25:151-194.

Miao, X. D., J. A. Mason, J. B. Swinehart, D. B. Loope, P. R. Hanson, R. J. Goble, and X. D. Liu. 2007. A 10,000 year record of dune activity, dust storms, and severe drought in the central Great Plains. Geology 35:119-122.

Miller, S. L., T. M. McClean, N. L. Stanton, and S. E. Williams. 1998. Mycorrhization, physiognomy, and first-year survivability of conifer seedlings following natural fire in Grand Teton National Park. Canadian Journal of Forest Research 28:115-122.

Millspaugh, S. H., C. Whitlock, and P. J. Bartlein. 2000. Variations in fire frequency and climate over the past 17000 yr in central Yellowstone National Park. Geology 28:211214.

Minckley, T. A., P. J. Bartlein, C. Whitlock, B. N. Shuman, J. W. Williams, and O. K. Davis. 2008. Associations among modern pollen, vegetation, and climate in western North America. Quaternary Science Reviews 27:1962-1991.

Minckley, T. A., and R. K. Shriver. 2011. Fire regime shifts in a Rocky Mountain forest, USA. Journal of Fire Ecology 7:6680.

Minckley, T. A., C. Whitlock, and P. J. Bartlein. 2007. Vegetation, fire, and climate history of the northwestern Great Basin during the last 14,000 years. Quaternary Science Reviews 26:2167-2184.

Monnin, E., A. Indermuhle, A. Dallenbach, J. Fluckiger, B. Stauffer, T. F. Stocker, D. Raynaud, and J. M. Barnola. 2001. Atmospheric $\mathrm{CO}_{2}$ concentrations over the last glacial termination. Science 291:112-114.

Nelson, D. M., and F. S. Hu. 2008. Patterns and drivers of Holocene vegetational change near the prairie-forest ecotone in Minnesota: revisiting McAndrews' transect. New Phytologist 179:449-459.

Overpeck, J. T., D. Rind, and R. Goldberg. 1990. Climateinduced changes in forest disturbance and vegetation. Nature 343:51-53.

Overpeck, J. T., T. Webb, and I. C. Prentice. 1985. Quantitative interpretation of fossil pollen spectra-dissimilarity coefficients and the method of modern analogs. Quaternary Research 23:87-108.
Peet, R. K. 1981. Forest vegetation of the Colorado Front Range - composition and dynamics. Vegetatio 45:3-75.

Prentice, I. C., W. Cramer, S. P. Harrison, R. Leemans, R. A. Monserud, and A. M. Solomon. 1992. A global biome model based on plant physiology and dominance, soil properties and climate. Journal of Biogeography 19:117-134.

Priestley, C. H. B., and R. J. Taylor. 1972. On the assessment of surface heat flux and evaporation using large-scale parameters. Monthly Weather Review 100:81-92.

Raffa, K. F., B. H. Aukema, B. J. Bentz, A. L. Carroll, J. A. Hicke, M. G. Turner, and W. H. Romme. 2008. Cross-scale drivers of natural disturbances prone to anthropogenic amplification: the dynamics of bark beetle eruptions. BioScience 58:501-517.

Reasoner, M. A., and M. A. Jodry. 2000. Rapid response of alpine timberline vegetation to the Younger Dryas climate oscillation in the Colorado Rocky Mountains, USA. Geology 28:51-54.

Reider, R. G. 1977. Radiocarbon dates from carbonate of soils on Bull Lake and Pinedale tills of the Libby Creek area, Medicine Bow Range, Wyoming. Contributions to Geology, University of Wyoming 15:67-72.

Reimer, P. J., et al. 2009. IntCal09 and Marine09 Radiocarbon Age Calibration Curves, 0-50,000 Years cal BP. Radiocarbon 51:1111-1150.

Romme, W. H., and D. G. Despain. 1989. Historical perspective on the Yellowstone fires of 1988. BioScience 39:695-699.

Romme, W. H., and D. H. Knight. 1981. Fire frequency and subalpine forest succession along a topographic gradient in Wyoming. Ecology 62:319-326.

Romme, W. H., and D. H. Knight. 1982. Landscape diversitythe concept applied to Yellowstone Park. BioScience 32:664670 .

Schoennagel, T., M. Turner, D. Kashian, and A. Fall. 2006. Influence of fire regimes on lodgepole pine stand age and density across the Yellowstone National Park (USA) landscape. Landscape Ecology 21:1281-1296.

Schoennagel, T., M. G. Turner, and W. H. Romme. 2003. The influence of fire interval and serotiny on postfire lodgepole pine density in Yellowstone National Park. Ecology 84:29672978.

Schoennagel, T., T. T. Veblen, and W. H. Romme. 2004. The interaction of fire, fuels, and climate across Rocky Mountain forests. BioScience 54:661-676.

Schoennagel, T., T. T. Veblen, W. H. Romme, J. S. Sibold, and E. R. Cook. 2005. ENSO and PDO variability affect drought-induced fire occurrence in Rocky Mountain subalpine forests. Ecological Applications 15:2000-2014.

Shinker, J. J., B. N. Shuman, T. A. Minckley, and A. K. Henderson. 2010. Climatic shifts in the availability of contested waters: a long-term perspective from the headwaters of the North Platte River. Annals of the Association of American Geographers 100:866-879.

Shuman, B. 2003. Controls on loss-on-ignition variation in cores from two shallow lakes in the northeastern United States. Journal of Paleolimnology 30:371-385.

Shuman, B., P. Bartlein, N. Logar, P. Newby, and T. Webb. 2002. Parallel climate and vegetation responses to the early Holocene collapse of the Laurentide Ice Sheet. Quaternary Science Reviews 21:1793-1805.

Shuman, B., A. K. Henderson, S. M. Colman, J. R. Stone, S. C. Fritz, L. R. Stevens, M. J. Power, and C. Whitlock. 2009. Holocene lake-level trends in the Rocky Mountains, USA. Quaternary Science Reviews 28:1861-1879.

Shuman, B., Y. S. Huang, P. Newby, and Y. Wang. 2006. Compound-specific isotopic analyses track changes in seasonal precipitation regimes in the Northeastern United States at ca $8200 \mathrm{cal}$ yrBP. Quaternary Science Reviews 25:29923002 . 
Shuman, B., P. Newby, Y. S. Huang, and T. Webb. 2004 Evidence for the close climatic control of New England vegetation history. Ecology 85:1297-1310.

Shuman, B., P. Pribyl, T. A. Minckley, and J. J. Shinker. 2010. Rapid hydrologic shifts and prolonged droughts in Rocky Mountain headwaters during the Holocene. Geophysical Research Letters 37:L06701.

Sibold, J. S., T. T. Veblen, and M. E. Gonzalez. 2006. Spatial and temporal variation in historic fire regimes in subalpine forests across the Colorado Front Range in Rocky Mountain National Park, Colorado, USA. Journal of Biogeography 33:631-647.

Stone, J. R., and S. C. Fritz. 2006. Multidecadal drought and Holocene climate instability in the Rocky Mountains. Geology 34:409-412.

Suding, K. N., and R. J. Hobbs. 2009. Threshold models in restoration and conservation: a developing framework. Trends in Ecology and Evolution 24:271-279.

Sugita, S. 1993. A model of pollen source area for an entire lake surface. Quaternary Research 39:239-244.

Sugita, S. 1994. Pollen representation of vegetation in Quaternary Sediments - theory and method in patchy vegetation. Journal of Ecology 82:881-897.

Thompson, R. S., K. H. Anderson, P. J. Bartlein, and S. A. Smith. 1999. Atlas of relations between climatic parameters and distributions of important trees and shrubs in North America. USGS Information Services, Denver, Colorado, USA.

Turner, M. G., W. H. Romme, and R. H. Gardner. 1999. Prefire heterogeneity, fire severity, and early postfire plant reestablishment in subalpine forests of Yellowstone National Park, Wyoming. International Journal of Wildland Fire 9:21-36.

Turner, M. G., W. H. Romme, R. H. Gardner, R. V. O'Neill, and T. K. Kratz. 1993. A revised concept of landscape equilibrium - disturbance and stability on scaled landscapes. Landscape Ecology 8:213-227.

Tweiten, M. A., S. C. Hotchkiss, R. K. Booth, R. R. Calcote, and E. A. Lynch. 2009. The response of a jack pine forest to late-Holocene climate variability in northwestern Wisconsin. Holocene 19:1049-1061.

van Mantgem, P. J., N. L. Stephenson, J. C. Byrne, L. D Daniels, J. F. Franklin, P. Z. Fule, M. E. Harmon, A. J. Larson, J. M. Smith, A. H. Taylor, and T. T. Veblen. 2009. Widespread increase of tree mortality rates in the western United States. Science 323:521-524.

Veblen, T. T. 2000. Disturbance patterns in southern Rocky Mountain forests. Pages 31-54 in R. L. Knight, F. W. Smith, S. W. Buskirk, W. H. Romme, and W. L. Baker, editors. Forest fragmentation in the southern Rocky Mountains. University Press of Colorado, Boulder, Colorado, USA.

Veblen, T. T., K. S. Hadley, and S. R. Marion. 1991. Disturbance and stand development of a Colorado subalpine forest. Journal of Biogeography 18:707-716.
Webb, T., III. 1986. Is vegetation in equilibrium with climate? How to interpret late-Quaternary pollen data. Vegetatio 67:75-91.

Weir, J. M. H., E. A. Johnson, and K. Miyanishi. 2000. Fire frequency and the spatial age mosaic of the mixed-wood boreal forest in western Canada. Ecological Applications 10:1162-1177.

Westerling, A. L., A. Gershunov, T. J. Brown, D. R. Cayan, and M. D. Dettinger. 2003. Climate and wildfire in the western United States. Bulletin of the American Meteorological Society 84:595-604.

Westerling, A. L., H. G. Hidalgo, D. R. Cayan, and T. W. Swetnam. 2006. Warming and earlier spring increase western US forest wildfire activity. Science 313:940-943.

Whipple, S. A., and R. L. Dix. 1979. Age structure and successional dynamics of a Colorado subalpine forest. American Midland Naturalist 101:142-158.

Whitlock, C., and P. J. Bartlein. 1993. Spatial variations of Holocene climatic-change in the Yellowstone Region. Quaternary Research 39:231-238.

Whitlock, C., C. E. Briles, M. C. Fernandez, and J. Gage. 2011. Holocene vegetation, fire and climate history of the Sawtooth Range, central Idaho, USA. Quaternary Research 75:114124.

Whitlock, C., and C. Larsen. 2001. Charcoal as a fire proxy. Pages 75-97 in J. P. Smol, H. J. B. Birks, and W. M. Last, editors. Tracking environmental change using lake sediments. Kluwer Academic Publishers, Dordrecht, The Netherlands.

Williams, J. W., and B. Shuman. 2008. Obtaining accurate and precise environmental reconstructions from the modern analog technique and North American surface pollen dataset. Quaternary Science Reviews 27:669-687.

Williams, J. W., B. Shuman, P. J. Bartlein, N. S. Diffenbaugh, and T. Webb. 2010. Rapid, time-transgressive, and variable responses to early Holocene midcontinental drying in North America. Geology 38:135-138.

Williams, J. W., et al. 2006. An Atlas of pollen-vegetationclimate relationships for the United States and Canada. American Association of Stratigraphic Palynologists Foundation, Dallas, Texas, USA.

Winkler, M. G. 1985. A 12,000-year history of vegetation and climate for Cape Cod, Massachusetts. Quaternary Research 23:301-312.

Worrall, J. J., L. Egeland, T. Eager, R. A. Mask, E. W. Johnson, P. A. Kemp, and W. D. Shepperd. 2008. Rapid mortality of Populus tremuloides in southwestern Colorado, USA. Forest Ecology and Management 255:686-696.

Wright, H. E. 1974. Landscape development, forest fires and wilderness management. Science 186:487-495.

Wulder, M. A., S. M. Ortlepp, J. C. White, T. Nelson, and N. C. Coops. 2010. A provincial and regional assessment of the mountain pine beetle epidemic in British Columbia: 1999-2008. Journal of Environmental Informatics 15:1-13.

\section{Supplemental Material}

Data Availability

Data associated with this paper have been deposited in Dryad: http://dx.doi.org/10.5061/dryad.1758mf $7 \mathrm{~b}$ 